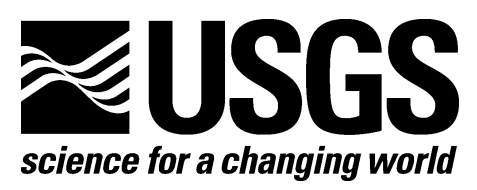

\title{
Compilation of Mineral Resource Data for Mississippi Valley-Type and Clastic-Dominated Sediment-Hosted Lead-Zinc Deposits
}

By Ryan D. Taylor, David L. Leach, Dwight C. Bradley, and Sergei A. Pisarevsky

Open-File Report 2009-1297

U.S. Department of the Interior

U.S. Geological Survey 


\section{U.S. Department of the Interior \\ KEN SALAZAR, Secretary}

\section{U.S. Geological Survey \\ Marcia K. McNutt, Director}

U.S. Geological Survey, Reston, Virginia: 2009

For product and ordering information:

World Wide Web: http://www.usgs.gov/pubprod

Telephone: 1-888-ASK-USGS

For more information on the USGS-the Federal source for science about the Earth,

its natural and living resources, natural hazards, and the environment:

World Wide Web: http://www.usgs.gov

Telephone: 1-888-ASK-USGS

Suggested citation:

Taylor, R.D., Leach, D.L., Bradley, D.C., and Pisarevsky, S.A., 2009, Compilation of mineral resource data for Mississippi Valley-type and clastic-dominated sediment-hosted lead-zinc deposits: U.S. Geological Survey Open-File Report 2009-1297, 42 p.

Any use of trade, product, or firm names is for descriptive purposes only and does not imply endorsement by the U.S. Government.

Although this report is in the public domain, permission must be secured from the individual copyright owners to reproduce any copyrighted material contained within this report. 


\section{Contents}

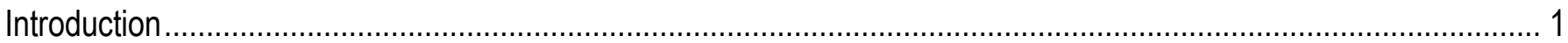

Clastic-Dominated and Mississippi Valley-Type Lead-Zinc Deposits................................................................... 2

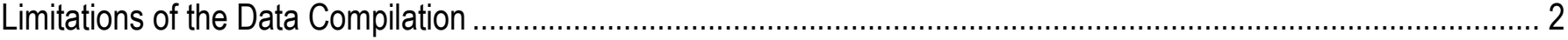

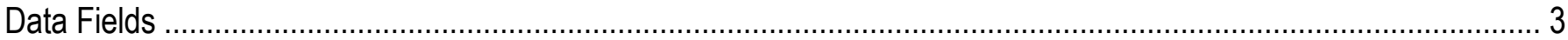

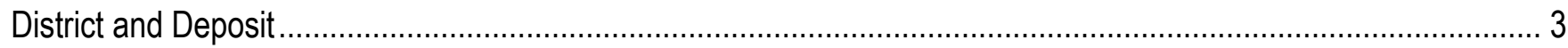

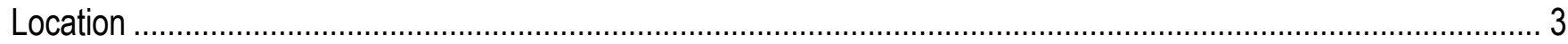

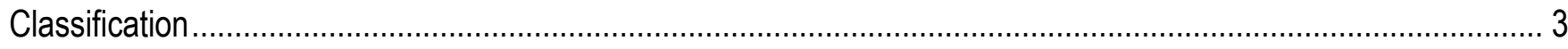

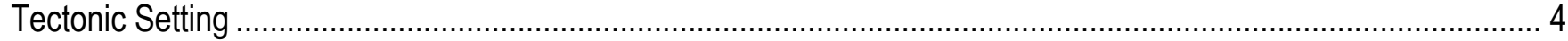

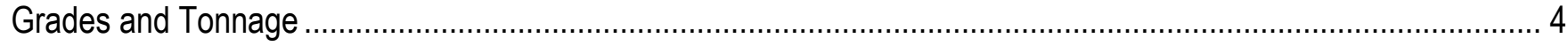

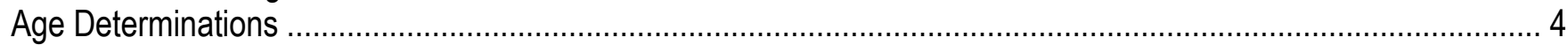

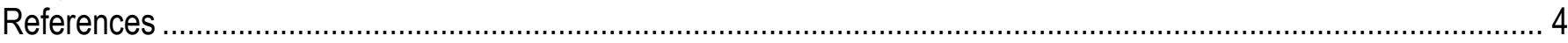

\section{Appendixes}

\section{Appendix A Tables}

A1. Global compilation of geologic and resource information for sediment-hosted lead-zinc deposits .......................29

A2. Compilation of age and resource information for selected sediment-hosted lead-zinc districts..............................33

\section{Appendix B Figures}

B1.Global distribution of clastic-dominated lead-zinc deposits and ancient passive margin sequences........................34

B2. Global distribution of Mississippi Valley-type lead-zinc deposits and districts ....................................................35

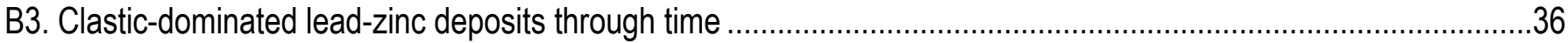

B4. Secular distribution of clastic-dominated lead-zinc deposits classified by their tectonic setting during

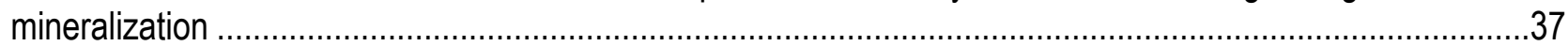

B5. Grade/tonnage for 121 clastic-dominated lead-zinc deposits ..........................................................................

B6. Secular distribution of Mississippi Valley-type metal and age of host rock .........................................................

B7. Grade-tonnage for 113 Mississippi Valley-type deposits and 10 districts ........................................................40

B8. Age of mineralization for Mississippi Valley-type districts and deposits ........................................................41

B9. Age of mineralization and host-rock for Mississippi Valley-type deposits and districts.......................................42 


\title{
Compilation of Mineral Resource Data for Mississippi Valley-Type and Clastic-Dominated Sediment-Hosted Lead-Zinc Deposits
}

\author{
By Ryan D. Taylor', David L. Leach¹, Dwight C. Bradley², and Sergei A. Pisarevsky³ \\ ${ }^{1}$ U.S. Geological Survey, Box 25046 Denver Federal Center, Denver, CO, U.S.A. \\ ${ }^{2}$ U.S. Geological Survey, 4200 University Drive, Anchorage, AK, USA 99508, U.S.A. \\ ${ }^{3}$ School of Geosciences, The University of Edinburgh, Grant Institute, West Mains Road, Edinburgh, UK UEH9 3JW, UK.
}

\section{Introduction}

This report contains a global compilation of the mineral resource data for sediment-hosted leadzinc (SH Pb-Zn) deposits. Sediment-hosted lead-zinc deposits are historically the most significant sources of lead and zinc, and are mined throughout the world. The most important $\mathrm{SH} \mathrm{Pb}-\mathrm{Zn}$ deposits

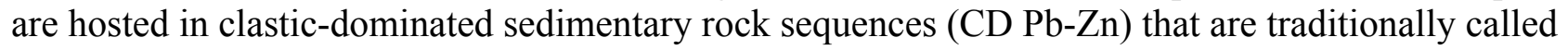
sedimentary exhalative (SEDEX) deposits, and those in carbonate-dominated sequences that are known as Mississippi Valley-type (MVT) Pb-Zn deposits. In this report, we do not include sandstone- $\mathrm{Pb}$, sandstone-hosted $\mathrm{Pb}$, or $\mathrm{Pb}-\mathrm{Zn}$ vein districts such as those in Freiberg, Germany, or Coeur d'Alene, Idaho, because these deposits probably represent different deposit types (Leach and others, 2005). We do not include fracture-controlled deposits in which fluorite is dominant and barite typically abundant (for example, Central Kentucky; Hansonburg, N. Mex.) or the stratabound fluorite-rich, but also leadand zinc-bearing deposits, such as those in southern Illinois, which are considered a genetic variant of carbonate-hosted $\mathrm{Pb}-\mathrm{Zn}$ deposits (Leach and Sangster, 1993).

This report updates the $\mathrm{Pb}, \mathrm{Zn}$, copper $(\mathrm{Cu})$, and silver $(\mathrm{Ag})$ grade and tonnage data in Leach and others (2005), which itself was based on efforts in the Canadian Geological Survey World Minerals Geoscience Database Project (contributions of D.F. Sangster to Sinclair and others, 1999). New geological or geochronological data, classifications of the tectonic environment in which the deposits formed, and key references to the geology of the deposits are presented in our report. Data for $121 \mathrm{CD}$ deposits, 113 MVT deposits, and 6 unclassified deposits that were previously classified as either SEDEX or MVT in the Leach and others (2005) compilation, are given in appendix table A1. In some cases, mineral resource data were available only for total district resources, but not for individual mines within the district. For these districts, the resource data are presented in appendix table A2. In addition, numerous figures (appendix figures B1-B9) displaying important grade-tonnage and geologic features are included.

These mineral deposit resource data are important for exploration targeting and mineral resource assessments. There is significant variability in the resource data for these deposit types, and ore controls vary from one region to another. Therefore, grade-tonnage estimations are best evaluated as subsets of 
the data in appendix table A1 where local mineralization styles and ore controls characterize the region being evaluated for grade-tonnage relations. Furthermore, consideration should also be given to the tendency for MVT resources to occur in large mineralized regions.

\section{Clastic-Dominated and Mississippi Valley-Type Lead-Zinc Deposits}

Classifications of the SH Pb-Zn ores in Leach and others (2005) were organized around traditional subgroups - MVT and SEDEX deposits - and were further subdivided based on classifications in the literature. A fundamental concern with the genetic-model-based classification of "SEDEX" is that it imparts an inherent "exhalative" genetic component to deposits. Most deposits classified as SEDEX lack unequivocal evidence of an exhalite in the ore or alteration component. Consequently, the presence of laminated sulfides parallel to bedding is commonly accepted to be permissive evidence for exhalative ore. However, some deposits traditionally classified as SEDEX did not form from sulfide exhalites. In this report, we avoid process-related, interpretive- and model-driven features to classify the deposits. Deposits are instead characterized by the nature of the sedimentary sequences and their interpreted tectonic environment within which the ores formed. This approach uses the relation that ores classified as SEDEX in Leach and others (2005) are hosted in clastic-dominated sedimentary rock sequences in mainly passive margin, continental rifts and sag basins. We use the term "clastic-dominated lead-zinc" (CD Pb-Zn) for these deposits and avoid genetic and temporal (for example, syngenetic, diagenetic, syn-diagenetic) attributes to the deposits. The ores can be hosted in shale, sandstone, siltstone, mixed clastic units, or as carbonate replacement ores within a clastic dominated sedimentary rock sequence. The CD deposits may be further subdivided based upon specific tectonic or geologic settings in which the deposit formed, which include passive margins (PM), continental rifts (RF), continental sag basins (CS), and back-arc basins (BA). An alternative classification of BHT (Broken Hill-type) is listed for some deposits, a subtype with unique characteristics similar to the Broken Hill, Australia, deposit (Leach and others, 2005).

We retain the traditional term of MVT $\mathrm{Pb}-\mathrm{Zn}$ for sediment-hosted $\mathrm{Pb}-\mathrm{Zn}$ deposits in carbonatedominated platform sequences because this terminology does not include a genetic component. Although the traditional use of the term MVT does imply a broad time component of simply being epigenetic with respect to its host rocks, we recognize that some MVT ores may have a syngenetic, diagenetic, or burial metamorphic temporal component to deposit or ore district formation. The most important characteristic of MVT deposits is their location, mainly hosted in dolostone and limestone in platform carbonate sequences and typically located at flanks of basins, orogenic forelands, or foreland thrust belts inboard of the clastic rock-dominated passive margin sequences. They have no spatial or temporal relations to igneous processes, which sets them apart from skarn or other magmatic $\mathrm{Pb}-\mathrm{Zn}$ ores.

Many subtypes or alternative classifications have been applied to MVT deposits since their inception as a distinct ore type by Bastin (1939). These alternative classifications reflect geographic and/or specific geological features that some workers believe set them apart as unique (for example, Appalachian-, Alpine-, Reocin-, Irish-, and Viburnum Trend-types). However, we do not consider these alternative classifications or subtypes to be sufficiently distinct to warrant using them in this report.

\section{Limitations of the Data Compilation}

Criteria used to classify the deposits and districts as MVT versus CD in appendixes A and B were based on the classifications assigned to the deposits in the literature and the opinions of the authors 
that relied on personal observations of the deposits or, in many cases, on descriptions of the geological setting and lithology of the ore-hosting sedimentary rock sequences. Six deposits are included in appendix A as "Unclassified" because the descriptions of the tectonic setting and host rock sequences were insufficient to allow confident discrimination between the two major types of $\mathrm{Pb}-\mathrm{Zn}$ deposits.

The resource information for the deposits is limited to publicly accessible resource information from sources cited in appendix tables A1 and A2. Some deposits and districts are not presented in the compilation (for example, Central Missouri and Northern Arkansas districts, U.S.A.), because publicly accessible resource information was not available for a variety of reasons. It should be noted that many factors (for example, metal prices, location, corporate policies, national politics, and so forth) influence the determination of the resource data in appendix tables A1 and A2. Furthermore, publicly available data (on which table A1 is based) are not necessarily the most recent. Therefore, the data in table A1, although considered to be the best currently available, do not necessarily reflect the true nature of mineralization in the ground.

Care must be taken with the usage of this data compilation because there are limitations to the data. Some resource data are old and have not been recently updated. Different deposits listed will be characterized by different metal cut-off grades in their definition of ore tonnages. Some deposits are still in the exploration phase and in the future are likely to have more accurate mineral resource estimates.

Many of the deposits do not have absolute mineralization ages listed, because of the difficulty of directly dating the ore minerals. Numerous papers have been published presenting dates of ore deposition, and careful consideration went into determining if the methods shown accurately reflect the age of ore formation, or something else. Dates deemed unreliable by the authors of this report have been excluded from this data compilation. Some deposits also have ambiguous or conflicting classifications reported in the literature. Caution was exercised in determining the correct deposit-type classification. Because this is a global compilation, aspects such as location, metal prices at the time of resource estimation, and regional politics all play roles in the resource estimates. Lastly, reporting of resource estimates is not as strictly controlled in some countries relative to others; therefore, overestimation of metal tonnages may characterize some deposits hosted in certain countries.

\section{Data Fields}

The attributes within the tables are defined below.

\section{District and Deposit}

The most commonly used names are provided in appendix table A1. Mississippi Valley-type deposits are characteristically distributed throughout larger districts. Many of these districts do not have resources defined for individual deposits; therefore, these are summarized in appendix table A2.

\section{Location}

The country and geographic location (latitude-longitude) for each deposit is listed. Latitude and longitude coordinates are provided in decimal format that were calculated using degrees, minutes, and seconds. Southern latitudes and western longitudes are listed as negative values.

\section{Classification}

Every deposit is identified as CD, MVT, or UN (unclassified). Alternative classifications (Alt. Class.) are supplied for select deposits as BHT (Broken Hill-type), carbonate-hosted/replacement, or sh- 
(shale) or cc- (coarse clastic) hosted. Also listed in the last three columns are the deposit-type classifications as cataloged in Leach and others (2005).

\section{Tectonic Setting}

When known, the tectonic settings (Tect. Setting) are listed as PM (passive margin), UN (unclassified), BA (back arc basin), CS (continental sag), or RF (rift).

\section{Grades and Tonnage}

The data listed include average grades and tonnage. If multiple cut-off grades were provided, our reported values are based on the lowest cut-off grade. Lead, zinc, and copper grades are shown as percentages. Silver and some other listed commodities are shown as grams per tonne $(\mathrm{g} / \mathrm{t})$. Deposit size and amount of metal are listed as Mt (million metric tonnes).

\section{Age Determinations}

Mineralization ages are all listed as Ma (million years ago). The method of age determination is listed. Host rock ages are listed using the geologic time scale (Walker and Geissman, 2009). Mineralization ages of CD deposits are typically coeval with host rock age.

\section{References}

Abbott, J.F., Gordey, S.P., and Tempelman-Kluit, D.J., 1986, Setting of stratiform, sediment-hosted lead-zinc deposits in Yukon and northeastern British Columbia: Canadian Institute of Mining and Metallurgy Special Volume 37, p. 1-18.

Admiralty Resources, 2009, Admiralty Resources website: Accessed October 30, 2009, at www.ady.com.au/index.php.

Anderson, I.K., Ashton, J.H., Boyce, A.J., Fallick, A.E., and Russell, M.J., 1998, Ore depositional processes in the Navan $\mathrm{Zn}-\mathrm{Pb}$ deposit, Ireland: Economic Geology, v. 93, p. 535-563.

Anderson, W.L., and Lydon, J.W., 1990, Sedex and MVT deposits in Jurassic carbonates of Pakistan [abs.]: Geological Survey of Canada Minerals Colloquium, Ottawa, Canada, August 12-18, 1990, Programs and Abstracts, p. 13.

Andrew, C.J., 1986, The tectono-stratigraphic controls to mineralization in the Silvermines area, County Tipperary, Ireland, in Andrew, C.J., Crowe, R.W.A., Finlay, S., Pennell, W.M., and Pyne, J.F., eds., Geology and genesis of mineral deposits in Ireland: Dublin, Irish Association for Economic Geology, p. 377-418.

Andrew, C.J., 1990, Irish zinc deposits-style and process in an orefield context: Institution of Mining and Metallurgy Bulletin, v. 1001, p. 9-16.

Andrew, C.J., 1995, The Silvermines district, Co. Tipperary, Ireland: Society of Economic Geologists Guidebook Series, v. 21, p. 247-259.

Andrew, C.J., and Poustie, A., 1986, Syndiagenetic or epigenetic mineralization - the evidence from the Tatestown zinc-lead prospect, Co. Meath, in Andrew, C.J., Crowe, R.W.A., Finlay, S., Pennel, W.M., and Pyne, J.F., eds., Geology and genesis of mineral deposits in Ireland: Dublin, Irish Association for Economic Geology, p. 281-296.

Anonymous, 1994, Far East_ — other metals and minerals: Mining Annual Review 1994, p. 113.

Anonymous, 1996, Rhonda confirms find of lead-zinc-silver in Territories: Northern Miner, October 14 issue, p. 14. 
Arne, D.C., 1991, Regional thermal history of the Pine Point area, Northwest Territories, Canada, from apatite fission track analysis: Economic Geology, v. 86, p. 428-435.

Arne, D.C., Duddy, I.R., and Sangster, D.F., 1990, Thermochronologic constraints on ore formation at the Gays River Pb-Zn deposit, Nova Scotia, Canada, from apatite fission track analysis: Canadian Journal of Earth Sciences, v. 27, p. 1013-1022.

Ashton, J.H., 1995, Guide to the geology of the Navan orebody: Society of Economic Geologists Guidebook Series, v. 21, p. 151-169.

Ashton, J., 2005, The Navan carbonate-hosted Zn-Pb deposit, Ireland: Ore Geology Reviews special issue on Geodynamics and Ore Deposit Evolution in Europe, v. 27, issue 1-4, p. 270.

Ashton, J.H., Downing, D.T., and Finlay, S., 1986, The geology of the Navan Zn-Pb orebody, in Andrew, C.J., Crowe, R.W.A., Finlay, S., Pennel, W.M., and Pyne, J.F., eds., Geology and genesis of mineral deposits in Ireland: Dublin, Irish Association for Economic Geology, p. 243-280.

Bachtadse, V., Van Der Voo, R., Haynes, F.M., and Kesler, S.E., 1987, Late Paleozoic magnetization of mineralized and unmineralized Ordovician carbonates from East Tennessee-evidence for a post-ore chemical event: Journal of Geophysical Research, v. 92, p. 14165-14176.

Bailes, R.J., Smee, B.W., Blackadar, D.W., and Gardner, H.D., 1986, Geology of the Jason lead-zincsilver deposits, Macmillan Pass, eastern Yukon: Canadian Institute of Mining and Metallurgy Special Volume 37, p. 87-99.

Bailey, A., 1998, Cannington silver-lead zinc deposit: Australasian Institute of Mining and Metallurgy Monograph 22, p. 783-792.

Bailie, R., Armstrong, R., and Reid, D., 2007, The Bushmanland Group supracrustal succession, Aggeneys, Bushmanland, South Africa: Provenance, age of deposition and metamorphism: South African Journal of Geology, vol. 110, p. 59-86.

Bancroft, P., Zorz, M., Krivograd, F., and Kobler, G., 1991, Famous mineral localities: The Mezica mine, Slovenia, Yugoslavia: Mineralogical Record, March-April 1991 issue, p. 97.

Barbanson, L., Touray, J.-C., Saulas, D., and Vadala, P., 1983, Distribution à différentes échelles et chronologie relative des arbonates de l'Aptien de la Province de Santander: Relation entre aurole Ferrifère et minéralisations $\mathrm{Zn}-\mathrm{Pb}$ du type Réocin: Chronique de la Récherche Minière, v. 473, p. 3948.

Bastin, E.S., 1939, Theories of formation of ore deposits: Scientific American, v. 49, no. 6, p. 538-547.

Basuki, N.I., Taylor, B.E., and Spooner, E.T.C., 2008, Sulfur isotope evidence for thermochemical reduction of dissolved sulfate in Mississippi Valley-type zinc-lead mineralization, Bongara area, northern Peru: Economic Geology, v. 103, p. 782-799.

Belperio, A.P., Priss, W.V., Fairclough, M.C., Gatehouse, C.G., Gum, J., Hough, J., and Burtt, A., 1998, Tectonic and metallogenic framework of the Cambrian Stansbury basin-Kanmantoo trough, South Australia: Australian Geological Survey Organisation Journal of Australian Geology and Geophysics, v. 17, p. 183-200.

Bjørlykke, A., Greene, T., Rui, I., and Vokes, F., 1980, A review of Caledonian stratabound sulphides in Norway: Geological Survey of Ireland Special Paper 5, p. 29-46.

Blake, D.H., Etheridge, M.A., Page, R.W., Stewart, A.J., Williams, P.R., and Wyborn, L.A.I., 1990, Mount Isa Inlier-regional geology and mineralization: Australasian Institute of Mining and Metallurgy Monograph 14, p. 915-925.

Boni, M., Lapponi, F., Schneider, J., Bechstadt, T., Liu, W., and Zheng, R., 2001, A preliminary Pb-Pb and U-Pb study on the MVT ore deposits in the Cambrian of Hunan (South China), in Pietsrzynski, A., ed., Mineral deposits at the beginning of the 21st century: Society for Geology Applied to Mineral Deposits (SGA), 6th biennial SGA-SEG meeting, Cracow, Poland, August 26-29, 2001, p. 117-120. 
Both, R.A., Mcelhinney, R., and Toteff, S., 1995, The Angas Zn-Pb-Ag deposit in the Kanmantoo Group, South Australia: synsedimentary or metamorphic?, Mineral Deposits: From Their Origin to Their Environmental Impact: Biennial SGA Meeting, 3rd, Prague, Czech Republic, 28-31 August 1995, Proceedings, p. 847-850.

Bouabdellah, M.L., Fontboté, L., Haeberlin, Y., Linares, L., Leach, D., and Spangenberg, J., 1999, Zoned sulphur isotope signatures at the Mississippi Valley-type Touissit Bou Becker, El Abed district, Morocco, Algeria - evidence for thermochemical sulphate reduction and mixing of sulphur sources, in Stanley, D.J., ed., Mineral deposits: Processes to processing: A.A. Balkema, p. 821-824.

Bradley, D.C., 2008, Passive margins through Earth history: Earth-Science Reviews, v. 91, p. 1-26.

Bradley, M.F., and Krolak, T.E., 1989, The Magmont-West lead-zinc-copper mine (Cominco American Incorporated-Dresser Minerals) Viburnum Trend, southeast Missouri, Mississippi Valley-type mineralization of the Viburnum Trend, Missouri: Society of Economic Geologists Field Conference Guidebook, v. 5, p. 84-95.

Bradley, O.E., 1970, Geology of the Jersey lead-zinc mine, Salmo, British Columbia, lead-zinc deposits in the Kootenay arc, northeastern Washington and adjacent British Columbia: Division of Mines and Geology, Department of Natural Resources, State of Washington, Bulletin 61, p. 89-98.

Brand, S.F., and Emo, G.T., 1986, A note on Zn-Pb-Ba mineralization near Oldcastle, Co. Meath, in Andrew, C.J., Crowe, R.W.A., Finlay, S., Pennell, W.M., and Pyne, J.F., eds., Geology and genesis of mineral deposits in Ireland: Dublin, Irish Association for Economic Geology, p. 297-304.

Brannon, J.C., Podosek, F.A., and Mclimans, R.K., 1993, Age and isotopic composition of gangue versus ore minerals in the Upper Mississippi Valley Zn-Pb district, in Shelton, K., and Hagni, R., eds., Geology and geochemistry of Mississippi Valley-type ore deposits, Proceedings volume: Rolla, University of Missouri Press, p. 95-103.

Brannon J.C., Dole, S.C., Podosek, F.A., Ragan, V.M., Coveney, Jr., R.M., Wallace, M.W., and Bradley, A.J., 1996, Th-Pb and U-Pb dating of ore-stage calcite and Paleozoic fluid flow: Science, v. 271, p. 491-493.

Brigo, L., and Omenetto, P., 1978, The lead and zinc ores of the Raibl (Cave del Predil, northern Italy) zone: new metallogenic data, section project 6: Diagnostic features of base metal occurrences in dolomites and limestones, in Zapfe, H., ed., Scientific results of the Austrian projects of the International Geological Correlation Programme (IGCP) until 1976, p. 103-110.

Brigo, L., Kostelka, L., Omenetto, P., Schneider, H.J., Schrool, E., Schulz, O., and Struel, I., 1977, Comparative reflections on four Alpine Pb-Zn deposits, in Klemm, D.D., and Schneider, H.-J., eds., Time and strata-bound ores: Springer Verlag, p. 273-293.

Briskey, J.A., Dingess, P.R., Smith, F., Gilbert, R.C., Armstrong, A.K., and Cole, G.P., 1986, Localization and source of Mississippi Valley-type zinc deposits in Tennessee, USA, and comparisons with Lower Carboniferous rocks of Ireland, in Andrew, C.J., Crowe, R.W.A., Finlay, S., Pennell, W.M., and Pyne, J.F., eds., Geology and genesis of mineral deposits in Ireland: Dublin, Irish Association for Economic Geology, p. 635-661.

Broadbent, G.C., and Waltho, A.E., 1998, Century zinc-lead-silver deposit: Australasian Institute of Mining and Metallurgy Monograph 22, p. 729-736.

Brock, J., 1973, Notes for delivery about Welcome North's interest in Godlin Lake, Northwest Territories: Vancouver, BC, Canada, Mineral Exploration Group, unpublished report, 13 p.

Brockie, D.C., Hare, E.H., Jr., and Dingess, P.R., 1968, The geology and ore deposits of the Tri-State district of Missouri, Kansas and Oklahoma, in Ridge, J.D., ed., Ore deposits of the United States, 1933-1967: The Graton-Sales volume: American Institute of Mining, Metallurgical and Petroleum Engineers, v. 1, p. 399-430. 
Brook Hunt, 2001, Lead/zinc mine cost study: London England, Brook Hunt Report.

Brown, A.G., and Romer, D.M., 1986, The geological setting and mineralization of the Carrickittle prospect, Co. Limeric, Ireland, in Andrew, C.J., Crowe, R.W.A., Finlay, S., Pennell, W.M., and Pyne, J.F., eds., Geology and genesis of mineral deposits in Ireland: Dublin, Irish Association for Economic Geology, p. 457-460.

Brown, W.H., and Weinberg, E.L., 1968, Geology of the Austinville-Ivanhoe district, Virginia, in Ridge, J.D., ed., Ore deposits of the United States, 1933-1967: The Graton-Sales volume: American Institute of Mining, Metallurgical and Petroleum Engineers, v. 1, p. 169-186.

Bugge, J.A.W., 1989, Norway, mineral deposits of Europe: Southwest and Eastern Europe, with Iceland: Institution of Mining and Metallurgy-Mineralogical Society [London] Special Volume 4/5, p. 199-249.

Caia, J., and Michaud, J.G., 1980, Aperçu sur les gisements de plomb et de zinc en milieu sédimentaire carbonate et détritique d'Eurodpe occidentale: Chronique de la Récherche Minière, no. 454, p. 38-40.

Callahan, W.H., 1968, Geology of the Friedensville zinc mine, Lehigh County, Pennsylvania, Ore Deposits of the United States, 1933-1967, in Ridge, J.D., ed., Ore deposits of the United States, 19331967: The Graton-Sales volume: American Institute of Mining, Metallurgical and Petroleum Engineers, v. 1, p. 95-107.

Canadian Zinc Corporation, [n.d.], Canadian Zinc Corporation website: Accessed October 30, 2009, at www.canadianzinc.com.

Caprock Corporation, 1991, Caprock Corporation announces mineral resource discovery at North Park property [press release]: Caprock Corporation Newletter.

Carmichael, A.J., 1988, The tectonics and mineralization of the Black Angel Pb-Zn deposits, Central West Greenland: University of London, Ph.D. dissertation, 369 p.

Carr, G.R., Denton, G.J., Korsch, M.J., Gardner, B.L., Parr, J.M., Andrew, A.S., Whitford, D.J., Wyborn, L.A.I., and Sun, S.S., 2001, User friendly isotope technologies in mineral exploration, northern Australian Proterozoic basins: AMIRA P480 Final Report: Commonwealth Scientific and Industrial Research Organisation Exploration and Mining Report 713C, 262 p.

Carrière, J.J., and Sangster, D.F., 1992, Preliminary studies of fluid inclusions in sphalerite, quartz, and dolomite from Gayna River MVT deposit, Northwest Territories: Current Research, Geological Survey of Canada Paper 92-01A, p. 47-53.

Casar, L., 1996, Ore mineralogy, textures and trace-element distributions at Raibl carbonate-hosted lead-zinc deposit, Tarvisio, Italy, with reference to treatment: Transactions of the Institution of Mining and Metallurgy, v. 105, p. B144-B149.

Cerny, I., 1989, Current prospecting strategy for carbonate-hosted $\mathrm{Pb}-\mathrm{Zn}$ mineralization at BliebergKreuth (Austria): Economic Geology, v. 84, p. 1430-1435.

Chagnon, A., St. Antonoin, P., Savard, M.M., and Héroux, Y., 1998, Impact of Pb-Zn sulfide precipitation on the clay mineral assemblage in the Gays River deposit, Nova Scotia, Canada: Economic Geology, v. 93, p. 779-792.

Chapman, L., 2001, Mineralization styles of the George Fisher Zn-Pb-Ag deposit, Mount Isa, Australia: Irish Association for Economic Geology Annual Review, p. 41.

Chapple, K., 2003, The Mehdiabad zinc deposit-Tethyan giant, in Elipoulos, D.D., ed., Mineral exploration and sustainable development: Rotterdam, Millpress, p. 1149-1152.

Cheng-Tu, M., Yi-Hsia, C., and Hung-Chuan, Y., 1978, The Guangmenshan Pb-Zn ore deposit-a deposit of the paleokarst type: Geology and Mineral Resources of Southeast Asia (GEOSEA), Regional Conference, 3rd, Bangkok, Thailand, November 14-18, 1978, Proceedings, p. 881-887. 
Christensen, J.N., Halliday, A.N., Vearncombe, J.R., and Kesler, S.E., 1995, Testing models of largescale fluid flow using direct dating of sulfides: Rb-Sr evidence of early dewatering and formation of MVT deposits: Economic Geology, v. 90, p. 877-884.

Christensen, N., Halliday, A.N., and Kesler, S.E., 1996, Rb-Sr dating of sphalerite and the ages of Mississippi Valley-type Pb-Zn deposits: Society of Economic Geologists Special Publication 4, p. 527-535.

Clayton, C.J., and Baird, A.W., 1997, Fluid flow, Pb-Zn mineralization, hydrocarbon maturation and migration in the Tunisian Atlas [ext. abs.]: Geofluids II '97, International Conference on Fluid Evolution, Migration, and Interaction in Sedimentary Basins and Orogenic Belts, 2nd, Extended Abstracts, p. 457-460.

Clifford, J.A., Ryan, P., and Kucha, H., 1986, A review of the geological setting of the Tynagh orebody, Co. Galway, in Andrew, C.J., Crowe, R.W.A., Finlay, S., Pennell, W.M., and Pyne, J.F., eds., Geology and genesis of mineral deposits in Ireland: Dublin, Irish Association for Economic Geology, p. 419-439.

CNNC, Central Records, Beijing.

Cominco Ltd., 2000, Cominco Limited Annual Report: Cominco Ltd.

Companhia Baiana de Pesuisa Mineral, [n.d.], Lead, zinc, and phosphate: Irece Carbonate basin: Companhia Baiana de Pesquisa Mineral (CBPM), Technical Summary.

Connor, A.G., 1990, Admiral Bay zinc-lead deposit: Australasian Institute of Mining and Metallurgy Monograph 14, p. 1111-1114.

Connor, A.G., Johnson, I.R., and Muir, M.D., 1990, Dugald River zinc-lead deposit: Australasian Institute of Mining and Metallurgy Monograph 14, p. 949-953.

Cook, R.B., Anbin, W., and Chunhui, S., 1991, Stratabound lead-zinc deposits of the Central Xicheng district, southeastern Gansu province, China: Mining Engineering, v. 43, p. 1165-1169.

Copper Ridge Explorations, Inc., 2003, Copper Ridge Explorations, Inc., website: Accessed October 30, 2009 at www.copper-ridge.com.

Cordilleran Engineering Limited, 1974, Summary report on the Goz Creek property: Cordilleran Engineering Limited, 1418-355 Burrard St., Vancouver, B.C., Property Report, 54 p.

Cornell, D.H., Pettersson, A., Whitehouse, M.J., and Schersten, A., 2009, A new chronostratigraphic paradigm for the age and tectonic history of the Mesoproterozoic Bushmanland Ore District, South Africa: Economic Geology, v. 104, p. 385-404.

Cox, M.W., 1968, Van Stone mine area (lead-zinc) Stevens County, Washington, in Ridge, J.D., ed., Ore deposits of the United States, 1933-1967: The Graton-Sales volume: American Institute of Mining, Metallurgical and Petroleum Engineers, v. 2, p. 1512-1519.

Cromie, P.W., Gosse, R.R., Zhang, P., and Zhu, X., 1996, Exploration for carbonate-hosted Pb-Zn deposits, Sichua, P.R.C. [abs.]: International Geological Congress, 30th, Beijing, China, Abstracts, p. 412.

Da Silva, R.C., Marques De Souza, I., and Brandai, W., 1988, Mina De Chumbo E Prata Do Perau, Andrianopolis, Parana, Principais Depositos Minerais Do Brasil, in Schobbenhaus, C., and Silva Coelho, C.E., eds., Matais basicos nao-ferrosos, ouro e aluminia: Republica Federativa do Brasil: Ministreio das Minas e Energia, Brasilia, v. III, p. 123-134.

Daitx, E.C., 1998, Os Depositos de Zinco e Chumbo de Perau Canoas e o Potencial do Vale do Ribeira, Workshop: Depositos Minerais Brasileiros de Metais-Base, 6-11 Septembro De 1998-Salvador-BahiaBrasil, p. 68-74.

Das Gupta, S.P., 1970, Sulfide deposits of Saladipura, Khetri copper belt, Rajasthan: Economic Geology, v. 65, p. 331-339. 
David, V., 2008, Structural-geological setting of the Elura Zn-Pb-Ag massive sulphide deposit, Australia: Ore Geology Reviews, v. 34, p. 428-444.

De Lorraine, W.F., and Dill, D.B., 1982, Structure, stratigraphic controls, and genesis of the Balmat zinc deposits, Northwest Adirondacks, New York: Geological Association of Canada Special Paper 25, p. 571-596.

De Lorraine, W.F., Dill, D.B., Knight, R.H., and Johnson, J.T., 1993, Geology of the Balmat zinc mines, St. Lawrence County, New York: Society of Economic Geologists Guidebook Series, v. 17, p. 26-48.

Deb, M., 1980, Genesis and metamorphism of two stratiform massive sulfide deposits at Ambaji and Deri in the Precambrian of western India: Economic Geology, v. 75, p. 572-591.

Deb, M., 1982, Lithogeochemistry of rocks around Rampura-Agucha massive zinc sulphide orebody, NW India-implications for the evolution of a Proterozoic "aulacogen": Precambrian Ore Deposits and Tectonics Meeting, Calcutta 1988, International Geological Correlation Programme (IGCP), Rotterdam, A.A. Balkema, p. 1-35.

Deb, M., and Bhattacharya, A.K., 1978, Geological setting and estimates of conditions of metamorphism of Rajpura-Dariba polymetallic ore deposit, Rajasthan, India: Mineralium Deposita, v. 13, p. 1-9.

Deb, M., and Kumar, R., 1982, The volcano-sedimentary environment of Rajpura-Dariba polymetallic ore deposit, Udaipur district, Rajasthan: Symposium on the Metallogeny of the Precambrian, International Geological Correlation Programme (IGCP) Project, Geological Survey of India, 91, p. 117.

Deb, M., and Sarkar, S.C., 1990, Proterozoic tectonic evolution and metallogenesis in the Aravalli-Delhi orogenic complex, Northwestern India: Precambrian Research, v. 46, p. 115-137.

Deb, M., and Sehgal, U., 1997, Petrology, geothermobarometry and C-O-H-S fluid compositions in the environs of Rampura-Agucha $\mathrm{Zn}-(\mathrm{Pb})$ ore deposit, Bhilwara district, Rajasthan: Proceedings of the Indian Academy of Science (Earth and Planetary Science), v. 104, p. 343-356.

Deb, M., and Thorpe, R.I., 2004, Geochronological constraints in the Precambrian geology of Rajasthan and their metallogenic implications, in Deb, M., and Goodfellow, W.D., eds., Sediment-hosted leadzinc sulphide deposits: New Delhi, India, Narosa Publishing House, p. 246-263.

Deb, M., Thorpe, R.I., Cumming, G.L., and Wagner, P.A., 1989, Age, source and stratigraphic implications of $\mathrm{Pb}$ isotope data for conformable, sediment-hosted, base metal deposits in the Proterozoic Aravalli-Delhi orogenic belt, Northwestern India: Precambrian Research, v. 43, p. 1-22.

Dejonghe, L., 1998, Zinc-lead deposits of Belgium: Ore Geology Reviews, v. 12, p. 329-354.

Dejonghe, L., Ladeuze, F., and Jans, D., 1993, Atlas des Fisements Plombozinciferes du Synclinorium de Verviers: Memoire, Ministere des Affaires Economiques de la Belgique, 33, 483 p.

Dewing, K., Sharp, R.J., and Turner, E., 2007, Synopsis of the Polaris Zn-Pb district, Canadian Arctic Islands, Nunavut, in Goodfellow, W.D., ed., Mineral deposits of Canada: a synthesis of major deposittypes, district metallogeny, the evolution of geological provinces, and exploration methods:

Geological Association of Canada, Mineral Deposits Division, Special Publication No. 5, p. 655-672.

Dingess, P.R., 1989, Geology of the Asarco West Fork deposit, Viburnum Trend-southeast Missouri, Mississippi Valley-type mineralization of the Viburnum Trend, Missouri: Society of Economic Geologists Field Conference Guidebook, v. 5, p. 96-110.

Dingess, P.R., and Erickson, L.A., 1995, Geology of the Asarco West Fork deposit, Viburnum Trend, Southeast Missouri: Society of Economic Geologists Guidebook Series, v. 22, p. 112-122.

Dings, M.G., and Whitebread, D.H., 1965, Geology and ore deposits of the Metaline zinc-lead district, Pend Oreille County, Washington: U.S. Geological Survey Professional Paper 489, 109 p. 
Distanov, E.G., Kovalev, K.R., Tarasova, R.S., Kochetkova, K.V., Ponomarev, V.G., Buslenko, A.I., and Gas'kov, I.V., 1982, The Kholodnyi pyrite-polymetallic deposit in the Precambrian of the Baikal region (Geological Survey of Canada Translation No. 3157), "Endogenous Ore Formations in Siberia" Series: Works of the Institute of Geology and Geophysics, v. 526, p. 1-207.

Dobretsov, N.L., 1996, Ore formation and global geological processes: evolution and problems of periodicity, in Smirnovskii Sbornik 96, general problems of ore formation and metallogeny: Moscow, Akademik Smirnov Fund, p. 38-60 (in Russian).

Dörling, S.L., Dentith, M.C., Groves, D.I., and Vearncombe, J.R., 1996, Mississippi Valley-type deposits of the southeast Lennard Shelf: an example of the interplay of extensional deformation, sedimentation and mineralization, in Sangster, D.F., ed., Carbonate-hosted lead-zinc deposits: Society of Economic Geologists Special Publication 4, p. 96-111.

Doyle, E., and Bowden, A.A., 1995, Field guide to the Galmoy zinc-lead deposits, Co. Kilkenny: Society of Economic Geologists Guidebook Series, v. 21, p. 139-149.

Doyle, E., Bowden, A.A., Jones, G.V., and Stanley, G.A., 1992, The geology of the Galmoy zinc-lead deposits, Co. Kilkenny, in Bowden, A.A., Earls, G., O’Connor, P.G., and Pyne, J.F., eds., The Irish minerals industry 1980-1990: Dublin, Irish Association for Economic Geology, p. 211-225.

Drew, G.J. and Both, R.A., 1984, The carbonate-hosted silver-lead deposits of the Ediacara mineral field, South Australia: petrological, fluid inclusion and sulphur isotope studies: Australian Journal of Earth Sciences, v. 31, p. 177-201.

Dunster, J.N., and Mcconachie, B.A., 1998, Tectono-sedimentary setting of the Lady Loretta Formation: synrift, sag or passive margin?: Australasian Journal of Earth Sciences, v. 45, p. 89-92.

Ehya, F., Lotfi, M., and Rasa, I., 2010, Emarat carbonate-hosted Zn-Pb deposit, Markazi Province, Iran: a geological, mineralogical and isotopic $(\mathrm{S}, \mathrm{Pb})$ study: Journal of Asian Earth Sciences, v. 37, p. 186194.

El Samani, Y., Touray, J.C., Pouit, G., and Guyot, G., 1986, La Mineralisation en Zn-Cu-Mn-Ba d'Abu Samar et les Indices de la Plaine d'Allaikaleib (Soudan): Des Accumulations Metalliferes Metamorphisees d'Origine Exhalative-Sedimentaire, Chronique de la Récherche Minière, v. 483, p. 318.

Emo, G.T., 1986, Some considerations regarding the styles of mineralization at Harberton Bridge, County Kildare, in Andrew, C.J., Crowe, R.W.A., Finlay, S., Pennell, W.M., and Pyne, J.F., eds., Geology and genesis of mineral deposits in Ireland: Dublin, Irish Association for Economic Geology, p. 461-469.

Escande, B., and Majeste-Menjoulas, C., 1985, Age Devonien Moyen a Superieur de la Succession Calcareo-Detritique a Mineralisations Stratiformes de la Region d'Arrens (Hautes Pyrenees): Bulletin de la Societe Geologique de France, v. 1, p. 277-279.

Fallara, F., Savard, M.M., and Paradis, S., 1998, A structural, petrographic, and geochemical study of the Jubilee $\mathrm{Zn}-\mathrm{Pb}$ deposit, Nova Scotia, Canada and a new metallogenic model: Economic Geology, v. 93, p. 757-778.

Fernandez-Martinez, J., and Velasco, E., 1996, The Troya Zn-Pb carbonate-hosted sedex deposit, northern Spain: Society of Economic Geologists Special Publication 4, p. 364-377.

Foglierini, F., Benard, A., and Verraes, G., 1980, Le Gisement des Malines (Gard) Zn, Pb, Fascicules sur les Gisments Francais 26CGIE (au nombre de 10): 26th International Geological Congress (Paris, 7-17 Juillet, 1980), Penarroya (Societe Miniere et Metallurgique), E5, 56 p.

Fontboté, L., and Gorzawski, H., 1990, Genesis of the Mississippi Valley-type Zn-Pb deposit of San Vincente, Central Peru: Geologic and isotopic (Sr, O, C, S, Pb) evidence: Economic Geology, v. 85, p. 1402-1437. 
Fontboté, L., Spangenberg, J., Oldham, L., Davila, D., and Febres, O., 1995, The Mississippi Valleytype zinc-lead mine of San Vicente, eastern Pucara basin, Peru [ext. abs.]: International Field Conference on Carbonate-Hosted Lead-Zinc Deposits, Society of Economic Geologists, St. Louis, Mo., Extended Abstracts, p. 83.

Forrest, K., and Sawkins, F.J., 1987, Geologic setting and mineralization of the Lik deposit: implications for the tectonic history of the western Brooks Range, in Tailleur, I., and Weimer, P., eds., Alaskan North Slope geology, Society of Economic Paleontologists and Mineralogists, p. 295-305.

Forrestal, P.J., 1990, Mount Isa and Hilton silver-lead-zinc deposits: Australasian Institute of Mining and Metallurgy Monograph 14, p. 927-934.

Forster, H., and Jafarzadeh, A., 1994, The Bafq mining district in central Iran - a highly mineralized infracambrian volcanic field: Economic Geology, v. 89, p. 1697-1721.

Frimmel, H.D., Deane, J.G., and Chadwick, P.J., 1996, Pan-African tectonism and the genesis of base metal sulfide deposits in the northern foreland of the Damara orogen, Namibia, in Sangster, D.F., ed., Carbonate hosted lead-zinc deposits: Society of Economic Geologists Special Publication 4, p. 204217.

Galley, A.G., Hannington, M.D., and Jonasson, I.R., 2007, Volcanogenic massive sulphide deposits, in Goodfellow, W.D., ed., Mineral deposits of Canada: A Synthesis of Major Deposit Types, District Metallogeny, the Evolution of Geological Provinces and Exploration Methods, p. 141-161.

Gandhi, S.M., 2001, The geology and mineralization of Rampura-Agucha zinc-lead deposit, India: Sediment-hosted lead-zinc sulfide deposits in the northwestern Indian Shield: International Workshop, Delhi-Udaipur, India, December 10-17, 2001, Proceedings, p. 227-249.

Gandhi, S.M., Paliwal, H.V., and Bhatnagar, S.N., 1984, Geology and ore reserve estimates of Rampura-Agucha zinc-lead deposit, Bhilwara district, Rajasthan: Journal of the Geological Society of India, v. 25, p. 659-705.

Gardiner, C.D., 1988, Canadian mines handbook 1988-1989: Northern Miner Press Limited, 7 Labatt Avenue, Toronto, Ontario M5A 3P2, 604 p.

Gaylord, W.B., 1995, Geology of the Elmwood and Gordonsville mines, Central Tennessee zinc district—an update: Society of Economic Geologists Guidebook Series, v. 22, p. 173-205.

Gaylord, W.B., and Briskey, J.A., 1983, Geology of the Elmwood and Gordonsville mines, Central Tennessee zinc district: Virginia Tech Department of Geological Sciences, Society of Economic Geologists, Tennessee Zinc Deposits Field Trip Guide Book 9, p. 116-151.

Gemmell, J.B., Zantop, H., and Meinert, L.D., 1992, Genesis of the Aguilar zinc-lead-silver deposit, Argentina: Contact metasomatic versus sedimentary exhalative: Economic Geology, v. 87, p. $2085-$ 2112.

Geological Survey of India, 1994, Detailed information on copper-lead-zinc ores in Rajasthan Gujarat (India): Geological Survey of India, 156 p.

Geoscience Australia, 2007, Australia's identified mineral resources 2007: Geoscience Australia, 96 p. Ghazanfari, F., 1998, Geology of the Angouran deposit, Iran: University of Tehran, M.Sc. thesis (in Farsi).

Ghazban, F., McNutt, R.H., and Schwarcz, H.P., 1994, Genesis of sediment-hosted Zn-Pb-Ba deposits in the Irankuh deposit, Esfahan area, west-central Iran: Economic Geology, v. 89, p. 1262-1278.

Ghimire, J.R., Khandka, R.K., and Chakrabarti, C.K., 1995, Zinc-lead mineralization in Ganesh Himal region, central Nepal: Journal of Nepal Geological Society, v. 14, p. 65-77.

Ghose, S., 1957, Lead-zinc-silver mineralization at Zawar, Rajasthan: Quarterly Journal_Geological, Mining and Metalurgical Society of India, v. 29, p. 56-64. 
Ghosh, A.K., Thorpe, R.I., and Chakrabarti, C.K., 2005, Interpretation of $\mathrm{Pb}$ and $\mathrm{S}$ isotope data for the Ganesh Himal metamorphosed stratiform $\mathrm{Zn}-\mathrm{Pb}$ deposit, central Nepal Himalaya: Journal of the Geological Society of India, v. 65, no. 6, p. 725-737.

Gibbs, A., 1976, Geology and genesis of the Bafq lead-zinc deposit, Iran: Institution of Mining and Metallurgy Transactions, sec. B, v. 85, p. B701-B716.

Golden Patriot Mining, Inc., 2004, Golden Patriot Mining Files Technical Report with TSX Venture Exchange for Ambaji Project in India that conforms with National Policy Instrument 43-101: News Release, August 26, 2004, 3 p.

Gomez Fernandez, F., and Arribas Moreno, A., 1994, Descripción de las mineralizaciones de Pb-Zn del sector sudeste de Picos de Europa (Norte de España). Implicaciones metalogenéticas: Boletin Geológico y Minero, v. 105, p. 249-262.

Goodfellow, W.D., and Jonasson, I.R., 1986, Environment of formation of the Howards Pass (XY) Zn$\mathrm{Pb}$ deposit, Selwyn basin: Canadian Institute of Mining and Metallurgy Special Volume 37, p. 19-50. Goodfellow, W.D., and Lydon, J.W., 2007, Sedimentary exhalative (SEDEX) deposits, in Goodfellow, W.D., ed., Mineral deposits of Canada: A Synthesis of Major Deposit Types, District Metallogeny, the Evolution of Geological Provinces and Exploration Methods, p. 163-184.

Goodfellow, W.D., and Rhodes, D., 1990, Geological setting, geochemistry and origin of the Tom stratiform Zn-Pb-Ag-barite deposits: Geological Survey of Canada Open File 2169, p. 177-241.

Grennan, E.F., 1986, Geology and genesis of the Courtbrown Pb-Zn-Ag deposit, in Andrew, C.J., Crowe, R.W.A., Finlay, S., Pennell, W.M., and Pyne, J.F., eds., Geology and genesis of mineral deposits in Ireland: Dublin, Irish Association for Economic Geology, p. 449-456.

Grundmann, W.H., Jr., 1977, Geology of the Viburnum 27 mine, Viburnum Trend, southeast Missouri: Economic Geology, v. 72, 349-364.

Gummer, P.K., Plint, H.E., and Rainbird, R.H., 1996, The Esker Lake prospect: stratabound Pb-Zn-CuAg in emergent inner shelf carbonates, Rocknest Formation, Coronation Supergroup, NWT, 1996 exploration overview: Canada Department of Indian Affairs and Northern Development, p. 18-19. Gutzmer, J., McClung, C.R., Beukes, N.J., Banks, D., Zwingmann, H., and Schaefer, M.O., 2007, Age and origin of the Earth's oldest carbonate-hosted Pb-Zn-(F) deposits, in Andrew, C.J., ed., Digging deeper; Proceedings of the Ninth Biennial Meeting of the Society for Geology Applied to Mineral Deposits, Dublin, Ireland 20th-23rd August 2007: Dublin, Irish Association for Economic Geology, p. 299-302.

Gwatkin, C., and Muccilli, P., 2002, Pillara mine-December 2001 resources and reserves report: Western Metals Limited internal report.

Hagni, R.D., 1995, The southeast Missouri lead district: Society of Economic Geologists Guidebook Series, v. 22, p. 44-78.

Hagni, R.D., and Coveney, R.M., Jr., 1989, Mississippi Valley-type mineralization of the Viburnum Trend, Missouri: Society of Economic Geologists Field Conference Guidebook v. 5, 193 p. Haldar, S.K., 2001, Grade-tonnage model for lead-zinc deposits of Rajasthan, India: IUGS-UNESCO, International Workshop, Sediment-Hosted Lead-Zinc Sulfide Deposits in the Northwestern Indian Shield, University of Delhi, Proceedings, p. 153-160.

Haldar, S.K., and Deb, M., 2001, Geology and mineralization of Rajpura-Dariba lead-zinc belt, Rajasthan: IUGS-UNESCO, International Workshop, Sediment-Hosted Lead-Zinc Sulfide Deposits in the Northwestern Indian Shield, Proceedings, p. 177-187.

Hall, C.M., York, D., Aunders, C.M., and Strong, D.F., 1989, Laser ${ }^{40} \mathrm{Ar} /{ }^{39} \mathrm{Ar}$ dating of Mississippi Valley-type mineralization from western Newfoundland [abs.]: International Geological Congress, Abstracts-Congres Geologique Internationale, Resumes, v. 28, p. 2.10-2.11. 
Hamilton, J.K., and Woodcock, J.T., 1993, Century zinc deposit of CRA Limited, North West Queensland: Australasian Institute of Mining and Metallurgy, Monograph Series 19, 2nd ed., p. 589590.

Hannak, W.W., 1981, Genesis of the Rammelsberg ore deposit near Goslar/Upper Harx, Federal Republic of Germany, in Wolf, K.H. ed., Handbook of strata-bound and stratiform ore deposits: New York, Elsevier Scientific Publishing, v. 9, p. 551-642.

Hassaan, M.M., 1990, Studies on lead-zinc sulphide mineralization in the Red Sea coastal zone, Egypt: Quadrennial IAGOD Symposium, 8th, in Conjunction with International Conference on Mineral Deposit Modeling, Proceedings, p. 835-847.

Haydon, R.C., and McConarchy, G.W., 1987, The stratigraphic setting of Pb-Zn-Ag mineralization at Broken Hill: Economic Geology, v. 82, p. 826-856.

Hayes, T.S., Kadi, K.A., Balkhiyour, M.B., Siddiqui, A.A., and Beshir, Z., 2000, Phanerozoic sedimenthosted base-metal mineralizing systems in Saudi Arabia: U.S. Geological Survey Technical Report IR-964, Ministry of Petroleum and Mineral Resources, Saudi Geological Survey, Jiddah, TR-00-3.

Heijlen, W., Muchez, P., Banks, D.A., Schneider, J., Kucha, H., and Keppens, E., 2003, Carbonatehosted $\mathrm{Zn}-\mathrm{Pb}$ deposits in Upper Silesia, Poland — origin and evolution of mineralizing fluids and constraints on genetic models: Economic Geology, v. 98, p. 911-932.

Henry, B., Rouvier, H., Le Goff, M., Leach, D.L., Macquar, J.C., Thibieroz, J., and Lewchuk, M.T., 2001, Paleomagnetic dating of widespread remagnetization on the southeastern border of the French Massif Central and implications for fluid-flow and MVT mineralization: Geophysics Journal International, v. 145, p. 368-380.

Henry, G., Charleswork, E.G., Master, S., and Stanistreet, I.G., 2002, The Tsongoari sedimentary exhalative sulphide deposits, Kakoland, Namibia: Quadrennial IAGOD Symposium and Geocongress 2002, 11th, Geological Survey of Namibia, Proceedings, Compact Disc.

Herald Resources, 2009, Herald Resources website: Accessed 12/28/2009 at www.herald.net.au

Hewton, R.S., 1982, Gayna River: a Proterozoic Mississipppi Valley-type zinc-lead deposit, Precambrian sulphide: Geological Association of Canada Special Paper 25, p. 668-700.

Heyl, A.V., Jr., Agnew, A.F., Lyons, E.J., and Behre, C.H., Jr., 1959, The geology of the Upper Mississippi Valley zinc-lead district: U.S. Geological Survey Professional Paper 309, 310 p.

Hitzman, M.W., 1986, Geology of the Abbeytown mine, Co. Sligo, Ireland, in Andrew, C.J., Crowe, R.W.A., Finlay, S., Pennell, W.M., and Pyne, J.F., eds., Geology and genesis of mineral deposits in Ireland: Dublin, Irish Association for Economic Geology, p. 341-354.

Hitzman, M.W., 1994, Argon-argon stepheating studies of muscovite in the Upper Devonian Old Red Sandstone-the first absolute dates for the age of Irish zinc-lead mineralization [abs.]: Geological Society of America, abstracts with programs, v. 26, no. 7, p. A-381.

Hitzman, M.W., and Beaty, D.W., 1996, The Irish Zn-Pb-(Ba-Ag) orefield: Society of Economic Geologists Special Publication 4, p. 112-143.

Hitzman, M.W., Thorman, C.H., Romagna, G., Oliviera, T.F., Dardennes, M.A., and Drew, L.J., 1995, The Morro Agudo Zn-Pb deposit, Minais Gerais, Brazil: a Proterozoic Irish-type carbonate-hosted Sedex-replacement (Irish-type) deposit [abs.]: Geological Society of America, Annual Meeting, New Orleans, Abstracts with Program, v. 27, no. 6, p. a-408.

Holdstock, M.P., 1982, Breccia-hosted zinc-lead mineralization in Tournaisian and lower Visean carbonates at Haberton Bridge, County Kildare, in Brown, A.G., ed., Mineral exploration in Ireland: Progress and developments 1971-1981: Dublin, Irish Association for Economic Geology, p. 83-91.

Holler, W., and Gandhi, S.M., 1995, Silver-bearing sulphosalts from the metamorphosed Rampura Agucha Zn-Pb-(Ag) deposit, Rajasthan, India: Canadian Mineralogist, v. 33, p. 1047-1057. 
Hou, B., and Zhao, D., 1993, Geology and genesis of the Baijaizi polymetallic sulfide deposits, Liaoning, China: International Geology Review, v. 35, p. 920-943.

Höy, T., 1977a, Kingfisher, Bright Star (82L/10) (FX, Fc, Colby), Geology in British Columbia, 1975 :

British Columbia Ministry of Energy, Mines and Petroleum Resources, Annual Report, p. G18-G30.

Höy, T., 1977b, Big Ledge (82L/8E), Geology in British Columbia, 1975: British Columbia Ministry of Energy, Mines and Petroleum Resources, Annual Report, p. G12-G18.

Höy, T., 1982, Stratigraphic and structural setting of stratabound lead-zinc deposits in southeastern BC: Canadian Institute of Mining and Metallurgy Bulletin, v. 75, p. 114-134.

Höy, T., 1987, Geology of the Cottonbelt lead-zinc-magnetite layer, carbonatites and alkalic rocks in the Mount Grace area, Frenchman Cap dome, southeastern British Columbia: British Columbia Geological Survey Branch Bulletin 80, 99 p.

HudBay Minerals, Inc., 2008, HudBay Announces Updated Mineral Reserves and Resources: News Release, Feb. 12, 2008.

Jankovic, S., 1986, The mineral association and genesis of the lead-zinc-barite deposit at Gunga, Khuzdar district, Baluchistan, Pakistan: GSP Rec. Mineral Resources, Ministry of Petroleum and Natural Resources, Quetta, v. LXXI, 23 p.

Jefferson, C.W., Kilby, D.B., Pigage, L.C., and Roberts, W.J., 1983, The Cirque barite-zinc-lead deposits, northeastern British Columbia: Mineralogical Association of Canada Short Course Handbook, v. 8, p. 121-140.

Jennings, D.S., and Jilson, G.A., 1986, Geology and sulphide deposits of Anvil Range, Yukon: Canadian Institute of Mining and Metallurgy Special volume 37, p. 319-361.

Jennings, S., and King, A.R., 2002, Geology, exploration history and future discoveries in the Red Dog district, Western Brooks Range, Alaska: Australia, University of Tasmania, CODES Special Publication 4, p. 151-160.

Jiang, S.-Y., Palmer, M.R., Li, Y.-H. and Xue, C.-J., 1995, Chemical compositions of tourmaline in the Yindongzi-Tongmugou $\mathrm{Pb}-\mathrm{Zn}$ deposits, Qinling, China: Implications for hydrothermal ore-forming processes: Mineralium Deposita, v. 30, p. 225-234.

Johansing, R.J., and Tompson, T.B., 1990, Geology and origin of Sherman-type deposits, central Colorado: Economic Geology Monograph 7, p. 367-394.

Johnson, I.R., and Klinger, G.D., 1975, Broken Hill ore deposit and its environment: Australasian Institute of Mining and Metallurgy Monograph Series 5, 3rd ed., p. 476-491.

Johnston, J.D., 1999, Regional fluid flow and the genesis of Irish carboniferous base metal deposits: Mineralium Deposita, v. 34, p. 571-598.

Jones, D., Bull, S., and McGoldrick, P., 1999, The Kamarga deposit: A large low grade stratabound zinc resource in the Proterozoic Carpentaria zinc belt of Northern Australia, in Stanley, C.J., ed., Mineral Deposits: Processes to Processing: A.A. Balkema, p. 873-876.

Jones, G.V., 1995, The Duddar Ge-Zn-Pb-Ba deposit, Balochistan, Pakistan: Irish Association for Economic Geology Annual Review, p. 101-111.

Jones, G.V., and Bradfer, N., 1982, The Ballinack zinc-lead deposit, Co. Westmeath, Ireland, in Brown, A.G., ed., Mineral exploration in Ireland: Progress and Developments 1971-1981: Dublin, Irish Association for Economic Geology, p. 47-62.

Jones, G.V., and Brand, S.F., 1986, The setting, styles of mineralization and mode of origin of the Ballinalack Zn-Pb deposit, in Andrew, C.J., Crowe, R.W.A., Finlay, S., Pennell, W.M., and Pyne, J.F., eds., Geology and genesis of mineral deposits in Ireland: Dublin, Irish Association for Economic Geology, p. 355-376. 
Jorgensen, G.C., Dendle, P.K., Rowley, M., and Lee, R.J., 1990, Sorby lead-zinc-silver deposit: Australasian Institute of Mining and Metallurgy Monograph 14, p. 1097-1101.

Kalenich, A.P., Kryukov, V.D., Latochkin, A.V., Semenov, Y.P., Zubarev, B.M., Volkov, B.K., Tsopanov, K., and Bur'yan, Y.I., 2002, New silver-bearing lead-zinc ore deposit in Novaya Zemlya: Razvedka I Okhrana Nedr, v. 2002, p. 20-23 (in Russian).

Karlstrom, K.E., Flurkey, A.J., and Houston, R.S., 1983, Stratigraphy and depositional setting of the Proterozoic Snowy Pass Supergroup, southeastern Wyoming: Record of an Early Proterozoic Atlantic-type cratonic margin: Geological Society of America Bulletin, v. 94, p. 1257-1274.

Khiltova, V.Ya., and Pleskach, G.P., 1997, Yenisey fold belt, in Rundqvist, D.V., and Gillen, C., eds., Precambrian ore deposits of the East European and Siberian cratons: Elsevier Science, p. 289-316.

King, A.R., Leach, D.L., Kelley, K.D., Clark, J.L., Young, L.E., Slack, J.F., De Vera, J., and Ayuso, R.A., 2002, A summary of ongoing research in the Red Dog district and possible applications to exploration, in Large, R.R. and others, eds., Stratiform Zn-Pb-Ag deposits and geological environments, with emphasis on the Australian and North American giants: Society of Economic Geologists/Prospectors and Developers Association of Canada Workshop, Toronto, March 2002, 6 p.

Klau, W., and Mostler, H., 1983, Alpine Middle and Upper Triassic Pb-Zn deposits, in Kisvarsanyi, G., Grant, S.K., Pratt, W.P., and Koenig, J.W., eds., Internation Conference on Mississippi Valley-type lead-zinc deposits: Proceedings volume: Rolla, University of Missouri Press, p. 113-128.

Kocer, S. and Sarac, C., 2001, Geology and geostatistical evaluation of Ilicadere (Bayindir, Izmir) PbZn mineralization: Geological Bulletin of Turkey, v. 44, no. 1, p. 27-36 (in Turkish).

Kontak, D.J., 1992, A preliminary report on geological, geochemical, fluid inclusion and isotopic studies of the Gays River Zn-Pb deposit, Nova Scotia: Nova Scotia Department of Natural Resources Open-File Report 92-014, 223 p.

Kontak, D.J., Farrar, E., and McBride, S.L., 1994, ${ }^{40} \mathrm{Ar} /{ }^{39} \mathrm{Ar}$ dating of fluid migration in a Mississippi Valley-type deposit: The Gays River Zn-Pb deposit, Nova Scotia, Canada: Economic Geology, v. 89, p. 1501-1517.

Kontak, D.J., Kyser, K., Gize, A., and Marshall, D., 2006, Structurally controlled vein barite mineralization in the Maritimes Basin of eastern Canada: geological setting, stable isotopes, and fluid inclusions: Economic Geology, v. 101, p. 407-430.

Krebs, W., 1981, The geology of the Meggen ore deposit, in Wolf, K.H., ed., Handbook of strata-bound and stratiform ore deposits: New York, Elsevier Scientific Publishing, v. 10, p. 509-549.

Kruger, F.J., Duane, M.J., and Whitelaw, H.T., 1999, The c.2 Ga Kheis tectonism in southern Africa and associated MVT mineralization, in Stanley, D.J., ed., Mineral deposits: Processes to processing: A.A. Balkema, p. 1263-1266.

Kruger, F.J., Duane, M.J., Turner, A.M., Whitelaw, H.T., and Verhagen, B.T., 2001, Paleohydrology of ca. 2 Ga old Mississippi Valley-type Pb-Zn deposits, South Africa: Radiogenic and stable isotope evidence: Economic Geology Research Institute, University of Witwatersrand, Information Circular $355,22 \mathrm{p}$.

Kyle, J.R., and Gutierrez, 1988, Origin of the Indian Creek sandstone-hosted lead deposits, southeast Missouri, U.S.A., in Zachrisson, E., ed., Proceedings of the Seventh Quadrennial IAGOD Symposium: E. Schweizerbart'sche Verlagsbuchhandlung, p. 669-684.

Kyle, J.R., and Misi, A., 1997, Origin of Zn-Pb-Ag sulfide mineralization within Upper Proterozoic phosphate-rich carbonate strata, Irece basin, Bahia, Brazil: International Geology Review, v. 39, p. 387-399. 
Lagny, P., 1975, Le Fisement Plombo-Aincifere de Salafossa (Alpes Italiennes Orientales): Remplissage d'un Paleokarst Triasique par des Sediments Sulfures: Mineralium Deposita, v. 10, p. 345-361.

Lane, T.E., 1990, Dolomitization, brecciation and zinc mineralization and their paragenetic, stratigraphic and structural relationships in the Upper St. George Group (Ordovician) at Daniel's Harbour, western Newfoundland: Memorial University of Newfoundland, Ph.D. dissertation, 262 p.

Large, D., and Walcher, E., 1999, The Rammelsberg massive sulphide $\mathrm{Cu}-\mathrm{Zn}-\mathrm{Pb}-\mathrm{Ba}$ deposit, Germany: an example of sediment-hosted, massive sulphide mineralization: Mineralium Deposita, v. 34, p. 522538.

Large, R.R., and McGoldrick, P.J., 1998, Lithogeochemical halos and geochemical vectors to stratiform sediment hosted $\mathrm{Zn}-\mathrm{Pb}-\mathrm{Ag}$ deposits, 1. Lady Loretta deposit, Queensland: Journal of Geochemical Exploration, v. 63, p. 37-56.

Large, R., Bull, S., Selley, D., Yang, J., Cooke, D., Garven, G., and McGoldrick, P., 2002, Controls on the formation of giant stratiform sediment-hosted $\mathrm{Zn}-\mathrm{Pb}-\mathrm{Ag}$ deposits: with particular reference to the north Australian Proterozoic: Australia, University of Tasmania, CODES Special Publication 4, p. 107-149.

Large, R.R., Bull, S., McGoldrick, P., Derrick, G., Carr, G., and Walters, S., 2005, Stratiform and stratibound $\mathrm{Zn}-\mathrm{Pb}-\mathrm{Ag}$ deposits of the Proterozoic sedimentary basins of northern Australia: Economic Geology 100th Anniversary Volume, p. 931-963.

Larin, A.M., Rytsk, Y.Y, and Sokolov, Yu, M., 1997, Baikal-Patom fold belt, in Rundqvist, D.V., and Gillen, C., eds., Precambrian ore deposits of the East European and Siberian cratons: Elsevier Science, p. 317-362.

Laznicka, P., 1981a, Data on the worldwide distribution of stratiform and stratabound ore deposits, in Wolfe, K.H., ed., Handbook of stratabound and stratiform ore deposits: Amsterdam, Elsevier, v. 9, p. 479-576.

Laznicka, P., 1981b, Data on the worldwide distribution of stratiform and stratabound ore deposits, in Wolfe, K.H., ed., Handbook of stratabound and statiform ore deposits: Amsterdam, Elsevier, v. 10, p. 79-390.

Lea, E.R., Dell, J., and David, B., 1968, Zinc deposits of the Balmat-Edwards district, New York, in Ridge, J.D., ed., Ore deposits of the United States, 1933-1967: The Graton-Sales volume: American Institute of Mining, Metallurgical and Petroleum Engineers, v. 1, p. 21-47.

Leach, D.L., and Sangster, D.F., 1993, Mississippi Valley-type lead-zinc deposits, in Kirkham R.V., Sinclair, W.D., Thorpe, R.I., Duke, J.M., eds., Mineral deposit models: Geological Association of Canada Special Paper 40, p 289-314.

Leach, D.L., Bechstädt, T., Boni, M., and Zeeh, S., 2003, Triassic-hosted Mississippi Valley-type Zn-Pb ores of Poland, Austria, Slovenia and Italy, in Kelly, J.G., Andrew, C.J., Ashton, J.H., Boland, M.E., Earls, G., Fusciardi, L. and Stanley, G. eds., Europe's major base metal deposits: Dublin, Irish Association for Economic Geology, p. 169-214.

Leach, D.L., Sangster, D.F. Kelley, K. D., Large, R. R., Garven, G., Allen, C. R., Gutzmer,J., and Walters, S., 2005, Sediment-hosted lead-zinc deposits: A global perspective: Economic Geology 100th Anniversary Volume, p. 561-608.

Lewchuk, M.T., and Symons, D.T.A., 1996, Paleomagnetism and Mississippi Valley-type ore genesis in the Ordovician Knox Supergroup of Central Tennessee: Society of Economic Geologists Special Publication 4, p. 567-576. 
Li, J. and Kusky, T.M., 2007, World's largest known Precambrian fossil black smoker chimneys and associated microbial vent communities, North China: implications for early life: Gondwana Research, v. 12 , p. $84-100$.

Li, W., Huang, Z., and Yin, M., 2006, Dating of the giant Huize Zn-Pb orefield of Yunnan Province, southwest China: constraints from the Sm-Nd system in hydrothermal calcite: Resource Geology, v. 57, no. 1, p. 90-97.

Li Wenbo, 2003, Sm-Nd dating of calcites from the Huize superlarge zinc-lead deposits of Yunnan province, southwest China [abs.]: Goldschmidt Conference, Kurashiki, Japan, September 7-12, 2003, Abstracts, p. A251.

Liaghat, S., Moore, F., and Jami, M., 2000, The Kuh-E-Surmeh mineralization, a carbonate-hosted Zn$\mathrm{Pb}$ deposit in the Simply Folded Belt of the Zagros Mountains, SW Iran: Mineralium Deposita, v. 35, p. $72-78$.

Lipson, R.D., 1990, Lithogeochemistry and origin of metasediments hosting the Broken Hill deposit, Aggeneys, South Africa, and implications for ore genesis: South Africa, University of Cape Town, Ph.D. dissertation, $250 \mathrm{p}$.

Lisenbee, A.L., 1988, Pb-Zn mineralization at Anjiren-Vejin mines, Sanandaj-Sirjan zone, Iran, in Kisvarsanyi, G., and Grant, S.K., eds., North American conference on tectonic control of ore deposits and the vertical and horizontal extent of ore systems: University of Rolla-Missouri Press, p. 180-187.

Liu, W., Boni, M., and Bechstadt, T., 1997, A first approach to the MVT ore deposits in the Cambrian of Hunan (southern China), in Papunen, H., ed., Mineral deposits: A.A. Balkema, p. 539-541.

Logan, R.G., Murray, W.J., and Williams, N., 1990, HYC silver-lead-zinc deposit, McArthur River: Australasian Institute of Mining and Metallurgy Monograph 14, p. 907-911.

Loudon, A.G., Lee, M.K., Dowling, J.F., and Bourn, R., 1975, Lady Loretta silver-lead-zinc deposit; Economic geology of Australia and Papua New Guinea: Australasian Institute of Mining and Metallurgy Monograph Series 5, 3rd ed., p. 377-382.

Lowther, J.M., Balding, A.B., McEvoy, F.M., Dunphy, S., MacEoin, P., Bowden, A.A., and McDermot, P., 2003, The Galmoy Zn-Pb orebodies: Structure and metal distribution — clues to the genesis of the deposits, in Kelly, J.G., Andrew, C.J., Ashton, J.H., Boland, M.E., Earls, G., Fusciardi, L. and Stanley, G. eds., Europe's major base metal deposits: Dublin, Irish Association for Economic Geology, p. 437-454.

Lu, J., Craig, J.R., and Rimstidt, J.D., 1995, Paragenesis and geochemistry of the Idol mine zinc deposit, Tennessee: Economic Geology, v. 90, p. 194-199.

Lydon, J.W., 1995, Sedimentary exhalative sulphides (Sedex): Geological Survey of Canada, Geology of Canada, no. 8, p. 130-152.

Lydon, J.W., 2000, A synopsis of the current understanding of the geological environment of the Sullivan deposit, Chapter 3, in Lydon, J.W., Höy, T., Slack, J.F., and Knapp, M., eds., The geological environment of the Sullivan deposit, British Columbia: Geological Association of Canada, Mineral Deposits Division, Special Publication No. 1, p. 12-31.

Ma, G., 2000, Geology and geochemistry of the Changba and Dengjiashan SEDEX lead-zinc deposits in the Qinling orogenic belt, China: Universite Lavale, Sainte-Foy, QC, Canada, M.Sc. thesis, 84 p.

Ma, G., Beaudoin, G., Qi, S., and Li, Y., 2004, Geology and geochemistry of the Changba SEDEX PbZn deposit, Qinling orogenic belt, China: Mineralium Deposita, v. 39, p. 380-395.

Macintyre, D.G., 1982, Geologic setting of recently discovered stratiform barite-sulphide deposits in northeast British Columbia: Bulletin of the Canadian Institute of Mining and Metallurgy, v. 75, p. 99103. 
Macintyre, D.G., 1983, Geology and stariform barite-sulphide deposits of the Gataga district, northeast British Columbia: Mineralogical Association of Canada Short Course Handbook, v. 8, p. 85-120.

Macintyre, D.G., 1991, SEDEX-sedimentary-exhalative deposits, ore deposits, tectonics and metallogeny in the Canadian Cordillera: British Columbia Ministry of Energy, Mines and Petroleum Resources Paper 1991-4, p. 25-70.

Macintyre, D.G., 1992, Geological setting and genesis of sedimentary exhalative barite and baritesulfide deposits, Gataga district, northeastern British Columbia: Exploration and Mining Geology, v. 1, p. 1-20.

Mackenzie, D.H., and Davies, R.H., 1990, Broken Hill lead-zilver-zinc deposit at Z.C. Mines: Australasian Institute of Mining and Metallurgy Monograph 14, p. 1079-1084.

Macquar, J.C., and Lagny, P.H., 1981, Mineralisations, Pb-Zn "Sous Inconformite" des Series de Platesformes Carbonatees. Exemple du Gisements de Treves (Gard, France). Relations Entre Dolomitisations, Dissolutions et Mineralisations: Mineralium Deposita. v. 16, p. 283-307.

Macquar, J.C., Rouvier, H., and Thibieroz, J., 1990, Les Mineralisations Zn, Pb, Fe, Ba, F, PeriCevenoles: Cadre Structuro-Sedimentaire et Distribution Spatio-Temporelle, Mobilité et Concentration des Métaux de Base dans les Couvertures Sédimentaire Manifestions, Mécanismes, Prospection: Doc BRGM Orleans, v. 183, p. 143-158.

Macqueen, R.W., and Thompson, R.I., 1978, Carbonate-hosted lead-zinc occurrences in northeastern British Columbia with emphasis on the Robb Lake deposit: Canadian Journal of Earth Sciences, v. 15, p. 1737-1762.

Maghreb Minerals, 2007, 8.8 million tonnes grading 3.16\% combined zinc and lead at the Gite de l'est deposit, Bou Jabeur: Maghreb Minerals Plc News Release, 13 December 2007.

Mathias, B.V., and Clark, G.J., 1975, Mount Isa copper and silver-lead-zinc orebodies-Isa and Hilton mines: Australasian Institute of Mining and Metallurgy Monograph Series 5, 3rd ed., p. 351-372.

McClay, K.R., and Bidwell, G.E., 1986, Geology of the Tom deposit, Macmillan Pass: Canadian Institute of Mining and Metallurgy Special Volume 37, p. 100-114.

McClung, C.R., Beukes, N.J., and Gutzmer, J., 2008, The basin analysis of the Bushmanland Group, northern Cape Province, South Africa: host to various polymetallic sulfide deposits, in Africa uncovered: Mineral resources for the future: SEG-GSSA 2008 Conference Abstract Book, Johannesburg, July 7-10, 196-197 pp.

McCracken, S.R., Etminan, H., Connor, A.G., and Williams, V.A., 1996, Geology of the Admiral Bay carbonate-hosted zinc-lead deposit, Canning basin, Western Australia: Society of Economic Geologists Special Publication 4, p. 330-349.

McKnight, E.T., 1935, Zinc and lead deposits of northern Arkansas: U.S. Geological Survey Bulletin 853, $311 \mathrm{p}$.

McLelland, J.M. and Chiarenzelli, J.R., 1990, Geochronological studies in the Adirondack Mountains and the implications of a Middle Proterozoic tonalitic suite, in Gower, C.F., Rivers, T., and Ryan, B., eds., Mid-Proterozoic Laurentia-Baltica: Geological Association of Canada, Special Paper 38, p. 175194.

MECL, 2009, MECL website: Accessed February 2009 at www.mecl.gov.in/SaleReportList.aspx.

Melcher, F., Oberthür, T., Vetter, U., Gross, C., Vollbrecht, A., Brauns, M., Haack, U., 2003, Germanium in carbonate-hosted $\mathrm{Cu}-\mathrm{Pb}-\mathrm{Zn}$ mineralization in the Otavi Mountain Land, Namibia, in Eliopoulos, D., and others, eds., Mineral exploration and sustainable development: Balkema, Rotterdam, p. 701-704.

Meridian Minerals Ltd, 2009, Quarterly report-1 January to 31 March, 2009: ASX Release 30 April 2009, Meridian Minerals Limited. 
Metals Economics Group, 1995, China: Emerging minerals opportunities: Halifax, Nova Scotia, Metals Economics Group, 335 p.

Meusy, G., 1986, Trip report-visit of St. Joe Resources Pierrepont mine, New York State, USA: St. Joe Resources Pierrepont Mine, Eldor Resources Limited, Exploration Division, 14 p.

Michaud, J.-G., 1976, Démarches et étapes dans la reconnaissance du gisement de Trèves, Gard (France mérionale): Mémoire hors série de la Société géologique de France, no. 7, p. 339-345.

Miller, D.C., and Wright, J., 1986, Mel barite-zinc-lead deposit, Yukon - an exploration case: Canadian Institute of Mining and Metallurgy Special Volume 37, p. 129-154.

MIM, 2002, Annual report: Mt Isa Mines Limited (MIM), Brisbane, Queensland.

Minceva-Steanova, J., 1967, The genesis of the stratiform lead-zinc ore deposits of the sedmochislenisi type in Bulgaria: Economic Geology Monograph 3, p. 147-154.

Misi, A., Iyer, S.S., Tassinari, C.C.G., Kyle, J.R., Coelho, C.E.S., Franca-Rocha, W.J.S., Gomes, A.S.R., and Cunha, I.A., 1999, Geological and isotopic constraints on the metallogenic evolution of the Proterozoic sediment-hosted Pb-Zn (Ag) deposits of Brazil: Gondwana Research, v. 2, p. 47-68.

Misra, K.C., and Fulweiler, R.E., 1995, Zinc deposits of the Mascot-Jefferson City district, east Tennessee: Society of Economic Geologists Guidebook Series, v. 22, p. 206-221.

Moharram, O., El Ramly, M.F., Gachechiladze, D.Z., and Ivanov, S.S., 1970, Studies on some mineral deposits of Egypt (summary of results of work carried out by a team of Egyptian and Soviet geologists under Contract 1247): United Arab Republic Ministry of Industry, Geological Survey.

Moore, J.M., 2002, A review of the geological setting of the Rosh Pinah and Skorpion base metal deposits: Quadrennial IAGOD Symposium and Geocongress 2002 Field Workshop, 11th, Rosh Pinah, Namibia, Proceedings, Compact Disc.

Morelli, R.M., Creaser, R.A., Selby, D., Kelly, K.D., Leach, D.L., and King, A.R., 2004, Re-Os sulfide geochronology of the Red Dog sediment-hosted $\mathrm{Zn}-\mathrm{Pb}-\mathrm{Ag}$ deposit, Brooks Range, Alaska: Economic Geology, v. 99, p. 1569-1576.

Mudan, Y., Wenbo, L., and Xiwen, S., 2009, Rb-Sr isotopic dating of sphalerite from the giant Huize $\mathrm{Zn}-\mathrm{Pb}$ ore field, Yunnan Province, southwestern China: Chinese Journal of Geochemistry, v. 28, $\mathrm{p}$. $70-75$.

Murphy, J.D., 1973, Mineral showings on Welcome North Mines Ltd.'s property in the Godlin Lakes area 105 P/14, 15 and 106 A/3 (63 50’N, 129 20’W): Indian Affairs and Northern Development Canada, Resident Geologist Report, 12 p.

Nakai, S., Halliday, A.N., Kesler, S.E., Jones, H.D., Kyle, J.R., and Lane, T.E., 1993, Rb-Sr dating of sphalerites from Mississippi Valley-type (MVT) ore deposits: Geochimica et Cosmochimica Acta, v. 57, p. 417-427.

Nandan, K.R.R., Rao, B.K.D., and Singhal, M.L., 1981, Exploration for copper, lead and zinc ores in India: Geological Survey of India Bulletin 47, 222 p.

Newbery, S.P., Carswell, J.T., Allnutt, S.L., and Mutton, A.J., 1993, The Dugald River zinc-lead-silver deposit: an example of a tectonised Proterozoic stratabound sulphide deposit: Australasian Institute of Mining and Metallurgy Publication Series 7/93, p. 7-21.

Ney, C.S., 1951, Ore deposits at Field, B.C.: Geology of the Monarch and Kicking Horse mines: Western Miner, v. 24, p. 51-60.

Ney, C.S., 1954, Monarch and Kicking Horse mines, Field, British Columbia: Alberta Association of Petroleum Geologists Field Conference, Banff-Golden-Radium, p. 119-136.

Ney, C.S., 1957a, Kootenay King mine, in Structural geology of Canadian ore deposits (Congress volume): Montreal, Mercury Press, p. 153-158. 
Ney, C.S., 1957b, Monarch and Kicking Horse mines, in Structural geology of Canadian ore deposits (Congress volume): Montreal, Mercury Press, p. 143-152.

Nielsen, B.L., 1976, Economic minerals, in Escher, A., and Watt, W.S., eds., Geology of Greenland, $630 \mathrm{p}$.

Nokleberg, W.J., Bundtzen, T.K., Berg, H.C., Brew, D.A., Grybeck, D., Robinson, M.S., Smith, T.E., and Yend, W., 1994, Metallogenic map of significant metalliferous lode deposits and placer districts in Alaska: The Geology of North America (GNA-G1), v. G-1, The Geological Society of America, plate 11 , scale 250,000 .

Northern Miner, 2009, Zazu likes lik: Northern Miner, May 28, 2009.

NTDME, 2002, Annual report: Northern Territory Department of Mines and Energy, Darwin, Northern Territory, Australia.

Omenetto, P., and Vailati, G., 1977, Ricerche Geominerarie nel Settore Cenrale del Distretto a Pb, Zn, Fluorite e Barite di Gorno (Lombardia): L’Industria Mineraria, v. 28, p. 25-44.

Oregeval, J.J., 1994, Peridiapiric metal concentration: example of the Bou Grine deposit (Tunisian Atlas): Society for Geology Applied to Mineral Deposits Special Publication 10, p. 354-389.

Otto, B.R., and Turner, R.J.W., 1989, Stratigraphic and structural setting of the Devonian-age Triumph stratiform zinc-lead-silver deposit, Milligen Formation, Warm Springs Mining District, Idaho: Northwest Mining Association, Annual Convention and Trade Show, 95th, Spokane, Washington, Preprint No. 19, 11 p.

Otto, B.R. and Zieg, G.A., 2003, Geology of an Ordovician stratiform base-metal deposit in the Long Canyon area, Blaine County, Idaho: U.S. Geological Survey Bulletin 2064-KK, 14 p.

OZ Minerals Ltd., 2008, Mineral resources explanatory notes as at 30 June 2008, chapter 6: OZ Minerals Ltd., p. 70-76.

Paarlberg, N.L., 1995, A guide to the geology of the Buick mine, Viburnum Trend: Society of Economic Geologists Guidebook Series, v. 22, p. 86-98.

Page, D.C., and Watson, M.D., 1976, The Pb-Zn deposit of Rosh Pinah mine, south west Africa: Economic Geology, v. 71, p. 306-327.

Page, R., Stevens, B., Gibson, G., and Conor, C.H.H., 2000, Geochronology of Willyama Supergroup rocks between Olary and Broken Hill, and comparison to northern Australia, in Broken Hill exploration initiative, 2000: Australian Geological Survey Organisation Record, v. 2000, no. 10, p. $72-75$.

Paiement, J-P., Beaudoin, G., and Paradis, S., 2007, Geological setting of Ag-Pb-Zn veins in the Purcell Basin, British Columbia: Geological Survey of Canada, Current Research 2007-A4, 12 p.

Pan, H., and Symons, D.T.A., 1993, Paleomagnetism of the Mississippi Valley-type Newfoundland zinc deposit: evidence for Devonian mineralization in the northern Appalachians: Journal of Geophysical Research, v. 98, p. 22415-22427.

Pan, H., Symons, D.T.A., and Sangster, D.F., 1990, Paleomagnetism of the Mississippi Valley-type ore and host rocks in the northern Arkansas and Tri-State districts: Canadian Journal of Earth Sciences, v. 27, p. 923-931.

Pan, H., Symons, D.T.A., and Sangster, D.F., 1993, Paleomagnetism of the Gays River zinc-lead deposit, Nova Scotia: Pennsylvanian ore genesis: Geophysical Research Letters, v. 20, p. 1159-1162.

Pannalal, S.J., Symons, D.T.A., and Sangster, D.F., 2008a, Paleomagnetic evidence for an Early Permian age of the Lisheen Zn-Pb-Ag deposit, Ireland: Economic Geology, v. 103, p. 1641-1655.

Pannalal, S.J., Symons, D.T.A., and Sangster, D.F., 2008b, Paleomagnetic evidence of a Variscan age for the epigenetic Galmoy zinc-lead deposit, Ireland: Terra Nova, v. 20, p. 385-393. 
Paradis, S., Nelson, J.L., and Zantvoort, W., 1999, A new look at the Robb Lake carbonate-hosted leadzinc deposit, northeastern British Columbia: Current Research, Geological Survey of Canada Paper 1999-A, p. 61-70.

Paradis, S., Chi, G. and Lavoie, D., 2004, Fluid inclusion and isotope evidence for the origin of the Upton Ba-Zn-Pb deposit, Quebec Appalachians, Canada: Economic Geology, v. 90, p. 807-817.

Paradis, S., Hannigan, M.D., and Dewing, K., 2007, Mississippi Valley-type lead-zinc deposits, in Goodfellow, W.D., ed., Mineral deposits of Canada: A Synthesis of Major Deposit Types, District Metallogeny, the Evolution of Geological Provinces and Exploration Methods, p. 185-204.

Parr, J.M., 1994, The geology of the Broken Hill-type Pinnacles Pb-Zn-Ag deposit, western New South Wales, Australia: Economic Geology, v. 89, p. 778-790.

Parr, J.M., Stevens, B.P.J., Carr, G.R., and Page, R.W., 2004, Subseafloor origin for Broken Hill Pb-ZnAg mineralization, New South Wales, Australia: Geology, v. 32, p. 589-592.

Pasminco Limited, 2000, Pasminco Limited Annual Report 2000: Pasminco Limited.

Pasminco Limited, 2001, Pasminco Limited Annual Report 2001: Pasminco Limited.

Pasminco Limited, 2002, Pasminco Limited Annual Report 2002: Pasminco Limited.

Pedersen, F.D., 1980, Remobilization of the massive sulfide ore of the Black Angel mine, central west Greenland: Economic Geology, v. 75, p. 1022-1041.

Pederson, M., 1997, Fluid inclusion geochemistry and lead isotope signatures of carbonate-hosted base metal-barite occurrences in the Jaameson Land basin, East Greenland: Society of Economic Geologists Special Publication 4, p. 234-236.

Peng, R., Zhai, Y., Deng, J., Xiao, R., and Wang, J., 2000, Ore-forming response to syndepositional submarine volcanism in Langshan-Zhaerai Mesoproterozoic SEDEX ore belt, Inner Mongolia, China: Journal of China University of Geosciences, v. 11, p. 302-307.

Pigage, L.C., 1987, Geology of the Cirque barite-zinc-lead deposits, northeastern British Columbia: Canadian Institute of Mining and Metallurgy Special Volume 37, p. 71-86.

Plumb, K.A., Ahmad, M., and Wygralak, A.S., 1998, Mid-Proterozoic basins of the North Australian craton: Australasian Institute of Mining and Metallurgy Monograph 22, p. 881-902.

Pouit, G., and Bois, J.-P., 1986, Arrens Zn (Pb), Ba Devonian deposit, Pyrenees, France: an exhalativesedimentary-type deposit similar to Meggen: Mineralium Deposita, v. 21, p. 181-189.

Poustie, A., and Kucha, H., 1986, The geological setting, style and petrology of zinc-lead mineralization in the Moyvoughly area, Co. Westmeath, in Andrew, C.J., Crowe, R.W.A., Finlay, S., Pennell, W.M., and Pyne, J.F., eds., Geology and genesis of mineral deposits in Ireland: Dublin, Irish Association for Economic Geology, p. 305-318.

Quinn, H.A., 1952, Renfrew: Renfrew and Lanark Counties, Ontario: Geological Survey of Canada Map 1046A.

Raghu Nandan, K.R., Bhruba Rao, B.K., and Singhal., M.L., 1989, Exploration for copper, lead and zinc ores in India: Geological Survey of India Bulletin, Series A., v. 47, 222 p.

Rainbird, R.H., 1997, Report on the stratigraphic and paleoenvironmental setting of stratabound Pb-Zn$\mathrm{Cu}$ in the Rocknest Formation, Epworth Group, Asiak fold-thrust belt, N.W.T.: Calgary, Alberta, Rhonda Mining Corporation, Internal Report, 18 p.

Randell, R.N., 1994, Geology of the Polaris Zn-Pb Mississippi Valley-type deposit, Canadian Arctic Archipelago: University of Toronto, Canada Ph.D. dissertation, 736 p.

Randell, R.N., and Anderson, G.M., 1996, Geology of the Polaris Zn-Pb deposit and surrounding area, Canadian Arctic Archipelago, in Sangster, D.F., ed., Carbonate-hosted lead-zinc deposits: Society of Economic Geologists Special Publication 4, p. 307-319. 
Rao, C.S.R., Poddary, B.C., and Chatterjee, A.K., 1972, Dariba-Rajpura-Bethumni belt of zinc-leadcopper mineralization, Udaipur district, Rajasthan: Base Metals: A Collection of Papers Presented at the Symposium, 5th and 6th July 1966, Calcutta, Geological Survey of India, p. 617-626 (2 volumes).

Reichert, J., and Borg, G., 2008, Numerical simulation and a geochemical model of supergene carbonate-hosted non-sulphide zinc deposits: Ore Geology Reviews, v. 33, p. 134-151.

Reid, C.J., 2001, Stratigraphy and mineralization of the Bongara MVT zinc-lead district, northern Peru: University of Toronto, Canada, M.Sc. thesis, 178 p.

Rhodes, D., Lantos, E.A., Lantos, J.A., Webb, R.J., and Owens, D.C., 1984, Pine Point orebodies and their relationship to the stratigraphy, structure, dolomitization, and karstification of the Middle Devonian Barrier Complex: Economic Geology, v. 79, p. 991-1055.

Ringrose, C.R., 1984, The geology and genesis of the Narlarla lead-zinc deposits, Napier Range, W.A., in Purcell, P.G., ed., The Canning basin: Perth, Geological Society of Australia, p. 455-462.

Robertson, J.F., 1963, Geology of the lead-zinc deposits in the Municipio de Januaria State of Minais Gerais Brazil: U.S. Geological Survey Bulletin 1110-B, 109 p.

Robinson, M., and Godwin, C.I., 1995, Genesis of the Blende carbonate-hosted Zn-Pb-Ag deposit, North-Central Yukon Territory: Geologic, fluid inclusion and isotopic constraints: Economic Geology, v. 90, p. 369-384.

Rogers, R.K., and Davis, J.H., 1977, Geology of the Buick mine, Viburnum Trend, southeast Missouri: Economic Geology, v. 72, p. 372-380.

Roonwal, G.S., and Wadhawan, S.K., 1980, Contribution to the metamorphism and deformational features of lead-zinc-pyrite mineralization at eastern Mochia, Zawar mines, Rajasthan, India: Indian Mineralogist, v. 21, p. 14-20.

Rouvier, H., Henry, B., Macquar, J.-C., Leach, D.L., Le Goff, M., Thibiéroz, J., and Lewchuk, M., 2001, Réaimantation régionale Eocène, migration de fluids et minéralisations sur la bordure cévenole (France): Bulletin de la Société Géologique de France, v. 4, p. 503-516.

Rozendaal, A., 1986, The Gamsberg zinc deposit, Namaqualand District, in Anhausser, C.R., and Maske, S., eds., Mineral deposits of southern Africa, volumes I and II: Geological Society of South Africa, p. 1477-1488.

Rozendaal, A., and Stumpfl, E.F., 1984, Mineral chemistry and genesis of Gamsberg zinc deposit, South Africa: Institution of Mining and Metallurgy, Transactions, section B, v. 93, p. B161-B175.

Ryan, P.J., Lawrence, A.L., Lipson, R.D., Moore, J.M., Paterson, A., Stedman, D.P., and Vanzyl, D., 1986, The Aggeneys base metal sulphide deposits, Namaqualand District, in Anhausser, C.R., and Maske, S., eds., Mineral deposits of southern Africa, volumes I and II: Geological Society of South Africa, p. 1447-1473.

Sarkar, S.C., Bhattacharyya, P.K., and Mukherjee, A.D., 1980, Evolution of the sulfide ores of the Saladipura, Rajasthan, India: Economic Geology, v. 75, p. 1152-1167.

Sarkar, S.C., Chernyshev, I.V., and Banerjee, H., 2000, Mid-Proterozoic Pb-Pb ages for some Himalayan base-metal deposits and comparison to deposits in Rajasthan, NW India: Precambrian Research, v. 99, p. 171-178.

Schmidt, J.M., 1997, Strata-bound carbonate-hosted Zn-Pb and $\mathrm{Cu}$ deposits of Alaska: Economic Geology Monograph 9, p. 90-119.

Schmidt, S.C., 1999, Re-activation of the Bougrine mine, Tunisia: Canadian Institute of Mining, Metallurgy, and Petroleum, 101st Annual General Meeting, Major Canadian Overseas Project Paper 1, p. 1-19.

Schneider, J., von Quadt, A., Wilkinson, J.J., and Boyce, A.J., 2007, Age of the Silvermines Irish-type $\mathrm{Zn}-\mathrm{Pb}$ deposit from direct $\mathrm{Rb}-\mathrm{Sr}$ dating of sphalerite, in Andrew, C.J., ed., Digging deeper; 
proceedings of the ninth biennial meeting of the Society for Geology Applied to Mineral Deposits, Dublin, Ireland 20th-23rd August 2007: Dublin, Irish Association for Economic Geology, p. 373-376. Schneider, J., Boni, M., Laukamp, C., Bechstädt, T. and Petzel, V., 2008, Willemite $\left(\mathrm{Zn}_{2} \mathrm{SiO}_{4}\right)$ as a possible $\mathrm{Rb}-\mathrm{Sr}$ geochronometer for dating nonsulfide $\mathrm{Zn}-\mathrm{Pb}$ mineralization: Examples from the Otavi Mountainland (Namibia): Ore Geology Reviews, v. 33, p. 152-167.

Schneider, W., Geng, A., and Liu, X., 1991, Diagenesis and mineralization processes in Devonian carbonate rocks of the Siding-Gudan lead-zinc mineral subdistrict, Guangxi, southwest China: Carbonates and Evaporites, v. 6, p. 53-67.

Schroeter, T.G., 1994, British Columbia mineral exploration review 1993: British Columbia Ministry of Energy, Mines and Petroleum Resources Information Circular 1994-1, p. 22.

Schroll, E., Kurzl, H., and Weinzierl, O., 1994, Geochemical studies applied to the Pb-Zn deposit Bleiberg/Austria, sediment-hosted Zn-Pb ores: Society for Geology Applied to Mineral Deposits Special Publication 10, p. 228-245.

Selby, D., Creaser, R.A., Dewing, K., and Fowler, M., 2005, Evaluation of bitumen as a ${ }^{187}$ Re- ${ }^{187}$ Os geochronometer for hydrocarbon maturation and migration: a test case from the Polaris MVT deposit, Canada: Earth and Planetary Science Letters, v. 25, p. 1-15.

Selwyn Resources Ltd., 2008, Selwyn Resources Ltd. website: Accessed February 2009 at www.selwynrsources.com/selwyn_resources.cfm.

Sharp, R.J., Ste-Marie, C.P., Lorenzini, C., Leigh, K.E., Dewing, K., Heroux, Y., and Chagnon, A., 1995, A field guide to the geology of the Polaris mine, Little Cornwallis Island, Northwest Territories, Canada: Society of Economic Geologists Guidebook Series, v. 22, p. 19-41.

Shearley, E., Redmond, P., Goodman, R., and King, M., 1995, A guide to the Lisheen Zn-Pb deposit: Society of Economic Geologists Guidebook Series v. 21, p. 123-137.

Sheppard, S.M.F., Charef, A., and Bouhlel, S., 1996, Diapirs and Zn-Pb mineralization: a general model based on Tunisia (N. Africa) and Gulf Coast (USA) deposits: Society of Economic Geologists Special Publication 4, p. 230-243.

Sherlock, R., Lee, J.K.E., and Cousens, B.L., 2004, Geological and geochronological constraints on the timing of mineralization at the Nanisivik zinc-lead Mississippi Valley-type deposit, northern Baffin Island, Nunavut, Canada: Economic Geology, v. 99, p. 279-293.

Shpikerman, V.I., 1987, Polymetallic mineralization of the Omulev uplift (the U.S.S.R. northeast): Vladivostok, Academy of Sciences, 164 p.

Sinclair, W.D., Chorlton, L.B., Laramee, R.M., Eckstrand, O.R., Kirkham, R.V., Dunne, K.P.E., and Good, D.J., 1999, World minerals geoscience database project: digital databases of generalized world geology and mineral deposits for mineral exploration and research, in Stanley, C.L., and others, eds., Mineral deposits: Processes to processing: Rotterdam, Balkema, p. 1435-1437.

Singh, N.N., 1988, Tectonic and stratigraphic framework of the lead-zinc sulphide mineralization at Zawarmala, District Udaipur, Rajasthan: Journal of the Geological Society of India, v. 31, p. 546-564. Skauli, H., Bjørlykke, A., and Thorpe, R.I., 1992, Lead-isotope study of the sulphide ore and alteration zone, Bleikvassli zinc-lead deposit, northern Norway: Mineralium Deposita, v. 27, p. 276-283.

Slowey, E.P., 1986, The Zn-Pb and barite deposits at Keel, Co. Longford, in Andrew, C.J., Crowe, R.W.A., Finlay, S., Pennell, W.M., and Pyne, J.F., eds., Geology and genesis of mineral deposits in Ireland: Dublin, Irish Association for Economic Geology, p. 319-330.

Smethurst, M.T., Symons, D.T.A., Sangster, D.F., and Lewchuk, M.T., 1999, Paleomagnetic age for Zn$\mathrm{Pb}$ mineralization at Robb Lake, northeastern British Columbia: Bulletin of Canadian Petroleum Geology, v. 47, p. 548-555. 
Smirnov, V.I., and Gorzhevsky, D.I., 1977, Deposits of lead and zinc, in Smirnov, V.I., ed., Ore deposits of the USSR: London, Pitman Publishing, p. 182-256.

Snyder, F.G., and Gerdemann, P.E., 1968, Geology of the southeast Missouri lead district, in Ridge, J.D., ed., Ore deposits of the United States, 1933-1967: The Graton-Sales volume: American Institute of Mining, Metallurgical and Petroleum Engineers, v. 1, p. 326-358.

Soever, A., and Meusy, G., 1986, The Cadieux (Renprior) zinc deposit, in Easton, R.M., Carter, T.R., and Springer, J.S., eds., Mineral deposits of the Central metasedimentary belt, Grenville Province, Ontario and Quebec: Geological Association of Canada, Mineralogical Association of Canada, Canadian Geophysical Union, Guidebook Field Trip 3, p. 43-45.

Song, X., 1994, Sediment-hosted $\mathrm{Pb}-\mathrm{Zn}$ deposits in China: mineralogy, geochemistry and comparison with some similar deposits in the world, in Fontbote, L., and Boni, M., eds., Sediment-hosted Zn-Pb ores: New York, Springer-Verlag p. 333-353.

Song, X., and Tan, H., 1996, Geochemical characteristics of the Fankou Pb-Zn deposit, northern Guangdong, South China: Society of Economic Geologists Special Publication 4, p. 350-355.

Southwood, M.J., 1986, The mineralogy of the Pering lead-zinc deposit, Cape Province, with special reference to supergene alteration, in Anhausser, C.R., and Maske, S., eds., Mineral deposits of southern Africa: Geological Society of South Africa, v. 1-2, p. 875-889.

Spry, P.G., Rosenberg, J.L., Jacobson, C.E., and Vokes, F.M., 1995, A metamorphic sulphidationoxidation halo associated with the Bleikvassli $\mathrm{Zn}-\mathrm{Pb}-(\mathrm{Cu})$ deposit, Nordland, Norway, in Pasava, J., Kribek, B., and Zak, K., eds., Mineral deposits: From their origin to their environmental impact: Rotterdam, Balkema, p. 909-912.

Stanistreet, I.G., and Charlesworth, E.G., 1999, Damaran basement-cored fold nappes incorporating precollisional basins, Kaoko Belt, Namibia, and controls on Mesozoic supercontinental break-up: Information Circular-University of the Witwatersrand, Economic Geology Research Unit, vol. 332, $14 \mathrm{p}$.

Stanistreet, I.G., and Charlesworth, E.G., 2001, Damaran basement-cored fold nappes incorporating precollisional basins, Kaoko Belt, Namibia, and controls on Mesozoic supercontinental break-up: South African Journal of Geology, 104, p. 1-12.

Stanton, R.L., and Vaughan, J.P., 1979, Facies of ore formation: A preliminary account of the Pegmont deposit as an example of potential relations between small "iron formations" and stratiform sulphide ores: Proceeedings of the Australasian Institute of Mining and Metallurgy, v. 270, p. 25-38.

Steers, J.E., 2003, Resource and reserve audit, Balmat no. 4 mine, Balmat-Edwards mining district, Balmat, N.Y., U.S.A.: Accessed 03/15/2009 at www.ontzinc.ca/news/balmat.pdf.

Stevens, B.P.J., Stroud, W.J., Willis, I.L., Brown, R.E., and Barnes, R.G., 1980, A stratigraphic interpretation of the Broken Hill block: Records of the Geological Survey of New South Wales, v. 20, pt. 1, p. 9-32.

Straczek, J.A., and Srikantan, B., 1996, Geology of the zinc-lead deposits of Modhia Magra: Geological Survey of India Memoir 92, p. 61-82.

Sureda, R.J., and Martin, J.L., 1990, El Aguilar mine: an Ordovician sediment-hosted stratiform leadzinc deposit in the Central Andes: Society for Geology Applied to Mineral Deposits Special Publication 8, p. 161-174.

Sutherland, R.A., and Dumka, D., 1995, Geology of the Nanisivik mine, N.W.T., Canada: Society of Economic Geologists Guidebook Series, v. 22, p. 4-18.

Sweeney, P.H., Harrison, E.D., and Bradley, M., 1977, Geology of the Magmont mine, Viburnum Trend, southeast Missouri: Economic Geology, v. 72, p. 365-371. 
Symons, D.T.A., 2007, Paleomagnetism of the HYC Zn-Pb SEDEX deposit, Australia: evidence of an epigenetic origin: Economic Geology, v. 102, p. 1295-1310.

Symons, D.T.A., and Arne, D.C., 2003, Paleomagnetic dating of mineralization in the Kapok MVT deposit, Lennard Shelf, Western Australia: Journal of Geochemical Exploration, v. 78-79, p. 267-272. Symons, D.T.A., and Arne, D.C., 2005, Paleomagnetic constraints on Zn-Pb ore genesis of the Pillara Mine, Lennard Shelf, Western Australia: Mineralium Deposita, v. 39, p. 944-959.

Symons, D.T.A., and Sangster, D.F., 1992, Late Devonian paleomagnetic age for the Polaris Mississippi Valley-type $\mathrm{Zn}-\mathrm{Pb}$ deposit, Canadian Arctic Archipelago: Canadian Journal of Earth Sciences, v. 29, p. $15-25$.

Symons, D.T.A., Pan, H., Sangster, D.G., and Jowett, E.C., 1993, Paleomanetism of the Pine Point ZnPb deposits: Canadian Journal of Earth Sciences, v. 30, p. 1028-1036.

Symons, D.T.A., Sangster, D.F., and Leach, D.L., 1995, A Tertiary age from paleomagnetism for the Mississippi Valley-type zinc-lead mineralization in Upper Silesia: Economic Geology, v. 90, p. 782794.

Symons, D.T.A., Lewchuk, M.T., Taylor, C.D., and Harris, M.J., 2000, Age of the Sherman-type Zn$\mathrm{Pb}-\mathrm{Ag}$ deposits, Mosquito Range, Colorado: Economic Geology, v. 95, p. 1489-1504.

Symons, D.T.A., Sangster, D.F., and Symons, T.B., 2001, The first direct dating of a Precambrian Mississippi Valley-type deposit; paleomagnetism of the Nanisivik mineralizing event, Arctic Archipelago, Canada [abs.]: Vietnam 2001 IAGA-IASPEI Joint Scientific Assembly, 19-31 August 2001, Hanoi, Vietnam, abstracts, p. 265.

Symons, D.T.A., Smethurst, M.T., and Ashton, J.H., 2002, Paleomagnetism of the Navan Zn-Pb deposit, Ireland: Economic Geology, v. 97, p. 997-1012.

Symons, D.T.A., Pannalal, S.J., Kawasaki, K., Sangster, D.F., and Stanley, G.A., 2007, Paleomagnetic age of the Magcobar Ba deposit, Silvermines, Ireland, in Andrew, C.J., ed., Digging deeper; proceedings of the ninth biennial meeting of the Society for Geology Applied to Mineral Deposits, Dublin, Ireland, 20th-23rd August 2007: Dublin, Irish Association for Economic Geology, p. 377380.

Symons, D.T.A., Lewchuck, M.T., Kawasaki, K., Velasco, F., Leach, D.L., 2009, The Reocin zinc-lead deposit, Spain — paleomagnetic dating of a late Tertiary ore body: Mineralium Deposita, v. 44, p. $867-$ 880.

The Northern Miner, 2003, Canadian Zinc puts Prairie Creek on the fast track: The Northern Miner, September 29, 2003, p. B6.

Thomassen, B., 1991, The Black Angel lead zinc mine 1973-90: Gronlands Geologiske Undersogelse Rapport 152, p. 46-50.

Thomassen, B., 2003, The Black Angel lead-zinc mine at Maarmorilik in West Greenland: Geological Survey of Denmark and Greenland (GEUS) 2003-2, 12 p.

Tiwary, A., and Deb, M., 1997, Geochemistry of hydrothermal alteration at the Deri massive sulphide deposit, Sirohi district, Rajasthan, NW India: Journal of Geochemical Exploration, v. 59, p. 99-121.

Tompkins, L.A., Pedone, V.A., Roche, M.T., and Groves, D.I., 1994, The Cadjebut deposit as an example of Mississippi Valley-type mineralization on the Lennard Shelf, Western Australia — single episode or multiple events?: Economic Geology, v. 89, p. 450-466.

Tompkins, L.A., Eisenlohr, B., Groves, D.I., and Raetz, M., 1997, Temporal changes in mineralization style at the Cadjebut Mississippi Valley-type deposit, Lennard Shelf, W.A.: Economic Geology, v. 92, p. 843-862.

Touahri, B., 1991, Geochimie et Metallogenie des Mineralisations a Plomb et Zinc du Nord de l'Algerie Office National de la Geologie, 18A Avenue Mustapha el Ouali, Alger: Memoires 4, 260 p. 
Touahri, B., 1997, Le Gisement de Zinc Plomb d'El abed, (Pays des Horsts Algero-Marocains): Environnement Geologique, les Dolomies, les Mineralisations, Notes et Memoires du Service Geologique, Royaume du Maroc, v. 388, p. 165-180.

Tse, P.-K., 2001, The Mineral industry of North Korea: U.S. Geological Survey Minerals Yearbook, p. 14.1

Tu Guangchi, 1990, Lead-zinc deposits of China, in Editorial Committee of Mineral Deposits of China, ed., Mineral deposits of China: Beijing, Geological Publishing House, p. 107-208.

Turner, R.J.W., 1990, Jason stratiform Zn-Pb-barite deposit, Selwyn basin, Canada (NTS 105-0-1): Geological Survey of Canada Open File 2169, p. 137-175.

Vadala, P., Touray, J.C., Garcia-Iglesias, J., and Ruiz, F., 1981, Nouvelles Donnees sur le Fisement de Reocin (Santander, Espange): Chronique de la Recherche Miniere, v. 462, p. 43-59.

Valdes-Nodarse, E.L., and Diaz-Carmona, A., 1993, Cogenetic SEDEX Zn-Pb and stockwork Cu ore, western Cuba: Exploration and Mining Geology, v. 2, p. 297-305.

Van Der Heyden, A., and Edgecombe, D.R., 1990, Silver-lead-zinc deposit at South mine, Broken Hill: Australasian Institute of Mining and Metallurgy Monograph 14, p. 1073-1077.

Van Der Stijl, F.W., and Mosher, G.Z., 1998, The Citronen Fjord massive sulphide deposit, Peary Land, North Greenland: Discovery, stratigraphy, mineralization and structural setting: Geology of Greenland Survey Bulletin, v. 179, p. 1-40.

Vaughan, J.P., and Stanton, R.L., 1986, Sedimentary and metamorphic factors in the development of the Pegmont stratiform $\mathrm{Pb}-\mathrm{Zn}$ deposit, Queensland, Australia: Institution of Mining and Metallurgy, Transactions, sec. B, V. 95, p. B94-B121.

Vearncombe, J.R., 1995, Other MVT deposits, zinc-lead mineralization on the southeast Lennard Shelf, Canning basin, Western Australia: Society of Economic Geologists Guidebook Series, v. 23, p. 136139.

Vearncombe, J.R., Dorling, S.L., and Rayner, M.J., 1995a, The Cadjebut orebody, zinc-lead mineralization on the southeast Lennard Shelf, Canning basin, Western Australia: Society of Economic Geologists Guidebook Series, v. 23, p. 81-102.

Vearncombe, J.R., Christensen, J.N., Dorling, S.L., McNaughton, N.J., and Reed, A.R., 1995b, The Blendevale orebody, zinc-lead mineralization on the southeast Lennard Shelf, Canning basin, Western Australia: Society of Economic Geologists Guidebook Series, v. 23, p. 103-135.

Vearncombe, J.R., Chisnall, A.W., Dentith, M.C., Dorling, S.L., Rayner, M.J., and Holyland, P.W., 1996, Structural controls on Mississippi Valley-type mineralization, the southeast Lennard Shelf, Western Australia: Society of Economic Geologists Special Publication 4, p. 74-95.

Vedanta Resources plc., 2008, Production and Reserves Summary: Vedanta Resources plc., 4 p.

Velasco, F., Herrero, J.M., Usta, I., Alonso, J.A., Seebold, I., and Leach, D., 2003, Geology and geochemistry of the Reocín zinc-lead deposit, Basque-Cantabrian basin, northern Spain: Economic Geology, v. 98, p. 1371-1396.

Vuuren, V., 1986, Regional setting and structure of the Rosh Pinah zinc-lead deposit, south west Africa/Namibia, in Anhausser, C.R., and Maske, S., eds., Mineral deposits of southern Africa: Geological Society of South Africa, v. 1-2, p. 1593-1607.

Wachowiak, N., Gummer, P.K., Pope, M., and Grotzinger, J.P., 1997, Stratabound Zn-Pb mineralization of the Esker horizon, Paleoproterozoic Rocknest Formation, Wopmay orogen, Canada [abs.]: NWT Geoscience Forum, 25th Anniversary, Yellowknife, Program and Abstracts of Talks and Posters, p. 96-98.

Wadjinny, A., 1997, Le District a Plomb-zinc de Touissit: Presentation Gitologique et Synthese des Travaux Realises: Notes et Memoires du Service Geologique, Royaume du Maroc, v. 388, p. 151-164. 
Walker, J.D., and Geissman, J.W., 2009, Geologic time scale: GSA Today, v. 19, no. 4/5, p. 60-61. Wallis, D.S., Draper, J.J., and Denaro, T.J., 1998, Palaeo- and Mesoproterozoic mineral deposits in Queensland: Journal of Australian Geology and Geophysics, v. 17, p. 47-59.

Walters, S.J., 1996, An overview of Broken Hill-type deposits: University of Tasmania, CODES Special Publication 1, p. 1-10.

Walther, H.W., 1986, Federal Republic of Germany, in Dunning, F.W., and Evans, A.M., eds., Mineral deposits of Europe: Central Europe: Institution of Mining and Metallurgy-Mineralogical Society, London, v. 3, p. 175-301.

Waltho, A.E., and Andrews, S.J., 1993, The Century zinc-lead deposit, northwest Queensland: Australasian Institute of Mining and Metallurgy, Centenary Conference, Proceedings, p. 41-61.

Waltho, A.E., Allnutt, S.L., and Radojkovic, A.M., 1993, Geology of the Century zinc deposit, northwest Queensland: Australasian Institute of Mining and Metallurgy Publication Series 7/93, p. 111-129.

Wang, X., Ahang, Z., Aheng, M., and Xu, X., 2000, Metallogenic mechanism of the Tianbaoshan Pb-Zn deposit, Sichuan: Chinese Journal of Geochemistry, v. 19, p. 121-133.

Wheatley, C.J.V., Friggens, P.J., and Dodge, F., 1986, The Bushy Park carbonate-hosted zinc-lead deposit, Griqualand West, in Anhausser, C.R., and Maske, S., eds., Mineral deposits of southern Africa: Geological Society of South Africa, v. 1-2, p. 891-900.

Whelan, J.F., Rye, R.O., and De Lorraine, W., 1984, The Balmat-Edwars zinc-lead depositssynsedimentary ore from Mississippi Valley-type fluids: Economic Geology, v. 79, p. 239-265.

Whitehead, R.E., Davies, J.F., Vales-Nodarse, E.L., and Diaz-Carmona, A., 1996, Mineralogical and chemical variations, Castellanos shale-hosted $\mathrm{Zn}-\mathrm{Pb}-\mathrm{Ba}$ deposit, northwestern Cuba: Economic Geology, v. 91, p. 713-722.

Williams, P.J., and Heinemann, M., 1993, Maramungee: a Proterozoic Zn skarn in the Cloncurry district, Mount Isa inlier, Queensland, Austalia: Economic Geology, v. 88, p. 1114-1134.

Wisniowiecki, M.J., Van Der Voo, R., Mccabe, C., and Kelly, W.C., 1983, A Pennsylvanian paleomagnetic pole from the mineralized Late Cambrian Bonneterre Formation, southeast Missouri: Journal of Geophysical Research, c. 88, p. 6540-6548.

Wright, J.V., Haydon, R.C., and McConachy, G.W., 1987, Sedimentary model for the giant Broken Hill $\mathrm{Pb}-\mathrm{Zn}$ deposit, Australia: Geology, v. 15, p. 598-602.

Xstrata Zinc, 2009, Ore reserves and mineral resources: Xstrata Zinc, 6 p.

Xuehui, X., 1996, Microbial mats in the Gaobanhe zinc-pyrite deposit, eastern Hebei, and the genesis of the deposit: Mineral Deposits, v. 15, p. 165-170.

Xuehui, X., 2001, Sedimentary exhalative massive sulfide deposits in the Proterozoic LangshanZhaertai rift in China: Exploration and Mining Geology, v. 8, p. 189-105.

Ye, L., and Liu, T., 1999, Sphalerite chemistry, Niujiaotang Cd-rich zinc deposit, Guizhou, southwest China: Chinese Journal of Geochemistry, v. 18, p. 62-68.

Yigit, O., 2009, Mineral deposits of Turkey in relation to Tethyan metallogeny-implications for future mineral exploration: Economic Geology, v. 104, p. 19-51.

Yukon Geological Survey, 2008, Yukon mineral deposits summary: Yukon Geological Survey, 16 p. Zapolnov, A.K., 1997, Tectonic evolution and metallogeny, in Rundqvist, D.V., and Gillen, C., eds., Precambrian ore deposits of the East European and Siberian cratons: Elsevier Science, p. 365-379. Zazu Metals Corp., 2009, Zazu's Lik South: over 3.3 Bn lbs. of indicated zinc resource: Zazu Metals Corp., News Release, May 28, 2009.

Zeeh, S., and Bechstadt, T., 1994, Carbonate-hosted Pb-Zn mineralization at Bleiberg-Kreuth (Austria): Society for Geology Applied to Mineral Deposits, v. 10, p. 271-296. 
Zhai, Y., Deng, J., and Peng, R., 1997, Some major mineral deposits in China: Their tectonic setting and deposit model characteristics: International Geological Congress, 30th, Beijing, China, Proceedings, v. 9 , p. 367-379.

Zheng, M., and Wang, X., 1991, Genesis of the Daliangzi Pb-Zn deposit in Sichuan, China: Economic Geology, v. 86, p. 831-846.

Zhou, C., Wei, C., Guo, J., and Li, C., 2001, The source of metals in the Qilinchang Zn-Pb deposit, northeastern Yunnan, China: Pb-Sr isotope constraints: Economic Geology, v. 96, p. 583-598.

Zieg, J., 2001, Metaline district, Washington: Northwest Mining Association, Pend Oreille Symposium and Field Trip, December 3-4, 2001, Guidebook.

Zongyao, R., Ning, L., and Longsheng, W., 1991, The Guanmenshan lead-zinc deposit: its basin brine ore-forming process and lead isotopic targeting: People's Republic of China Ministry of Geology and Mineral Resources, Beijing, Geological Publishing House, Geological Memoirs 4, 208 p. 


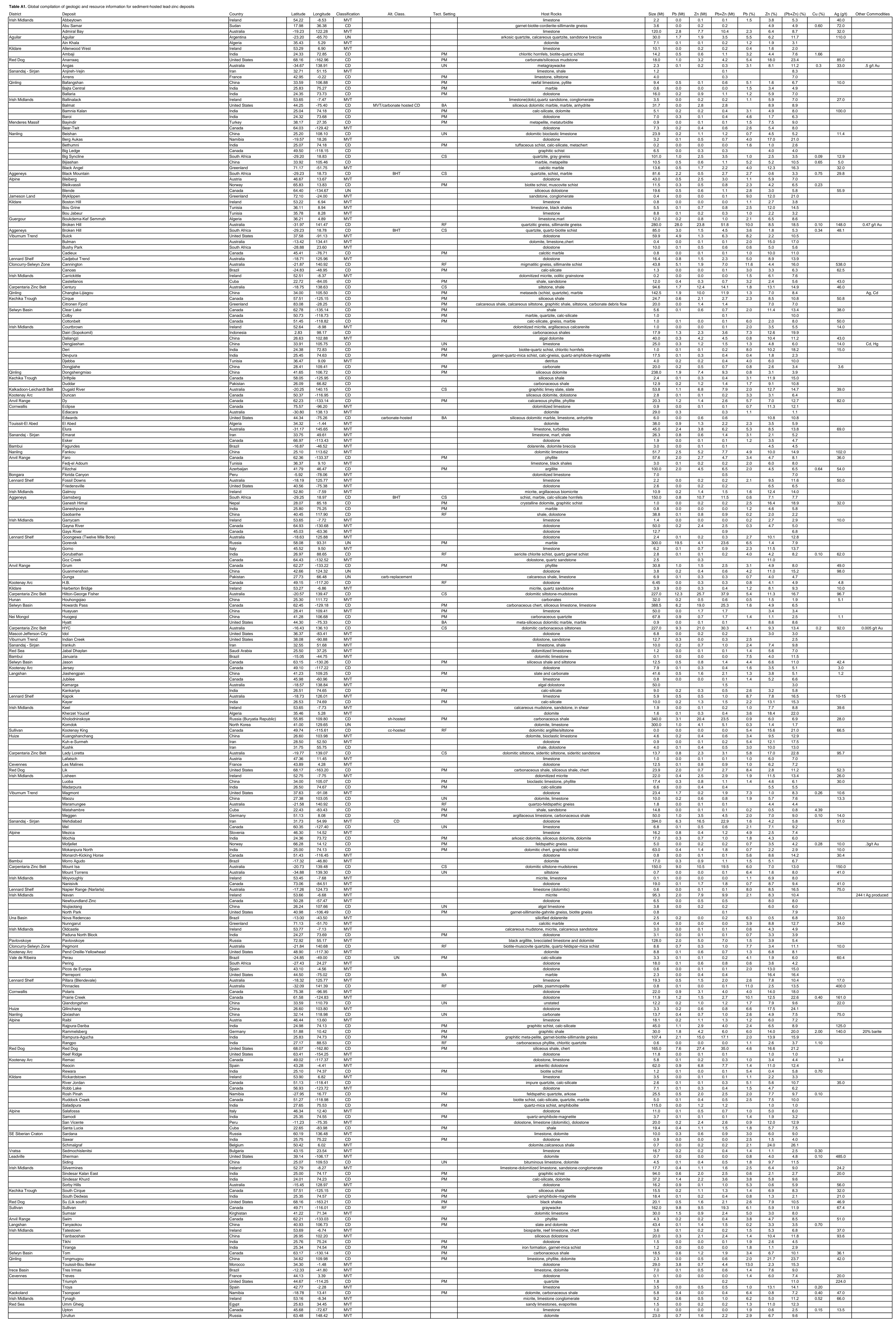




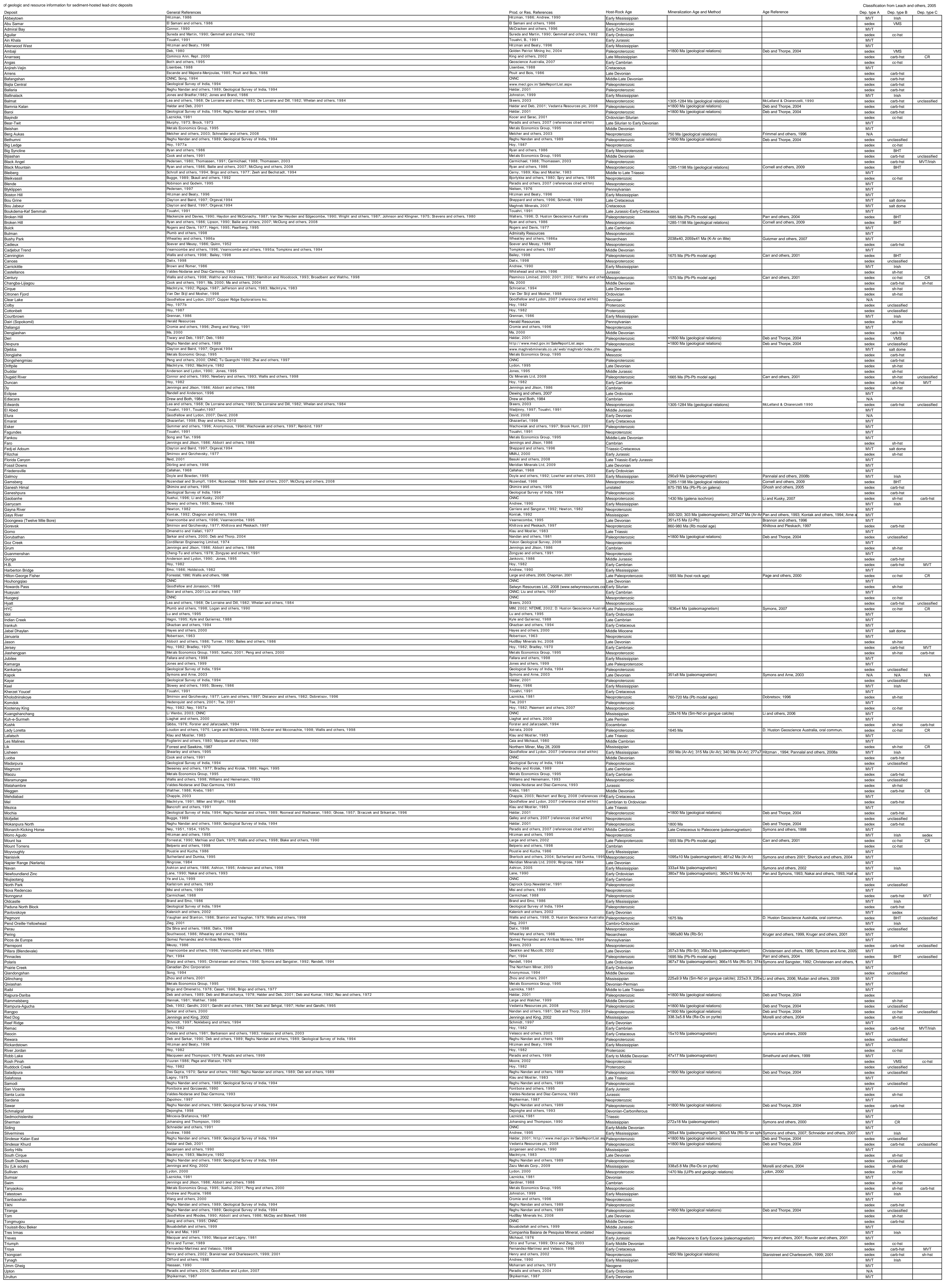




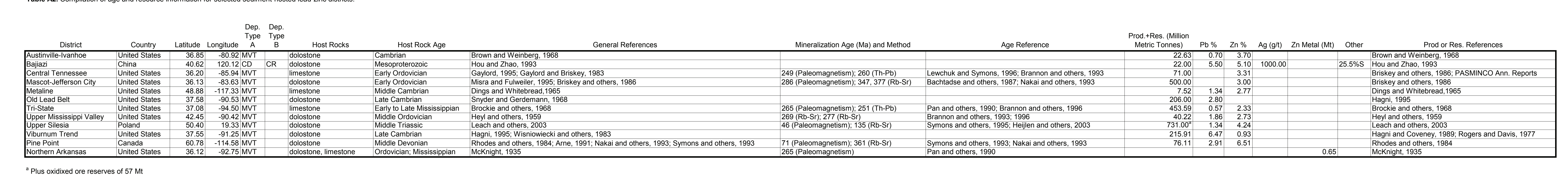

Mineraization Age (Ma) and Method 


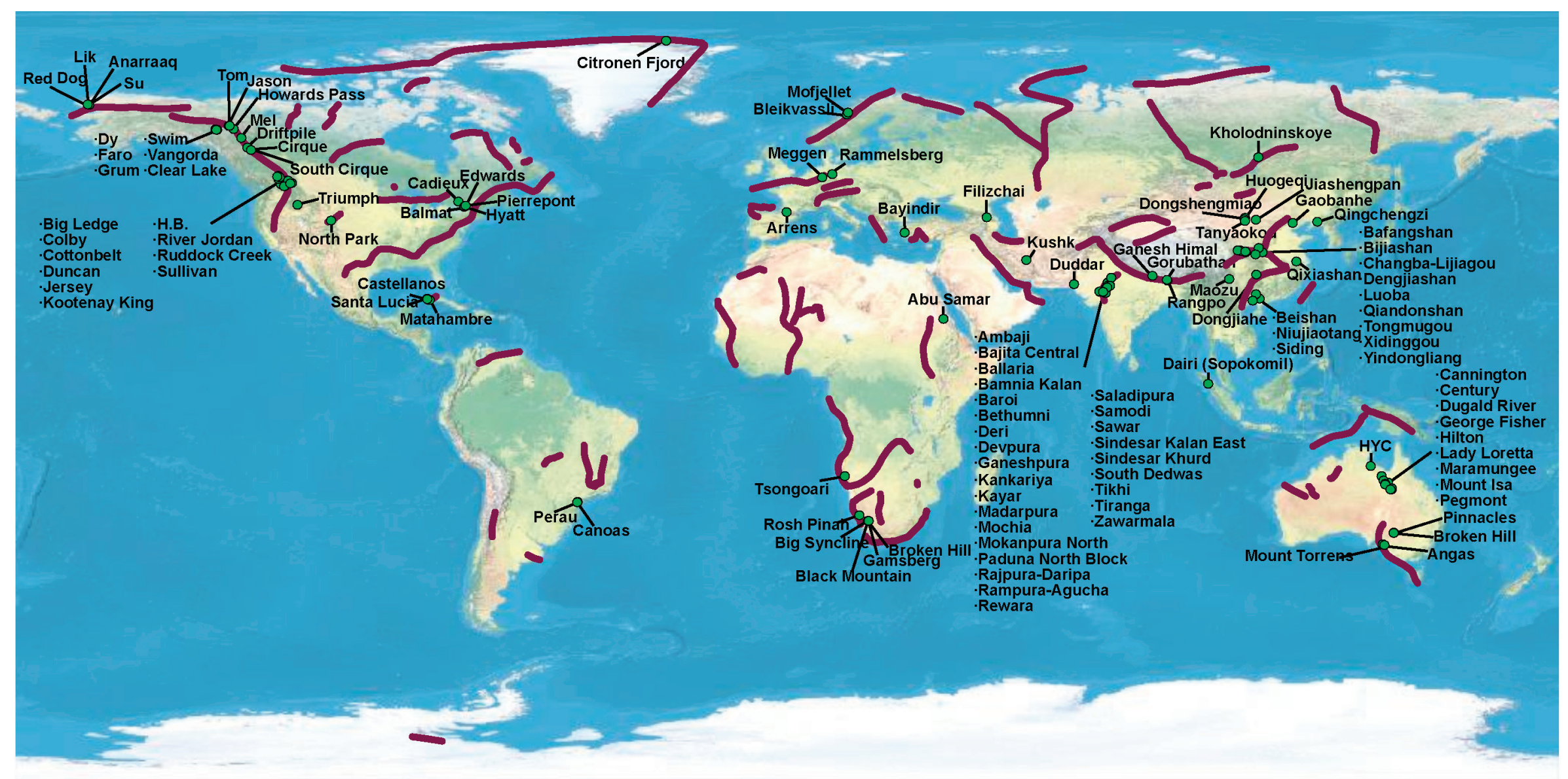

Figure B1. Global distribution of clastic-dominated lead-zinc deposits and ancient passive margin sequences (shown as purple lines). 


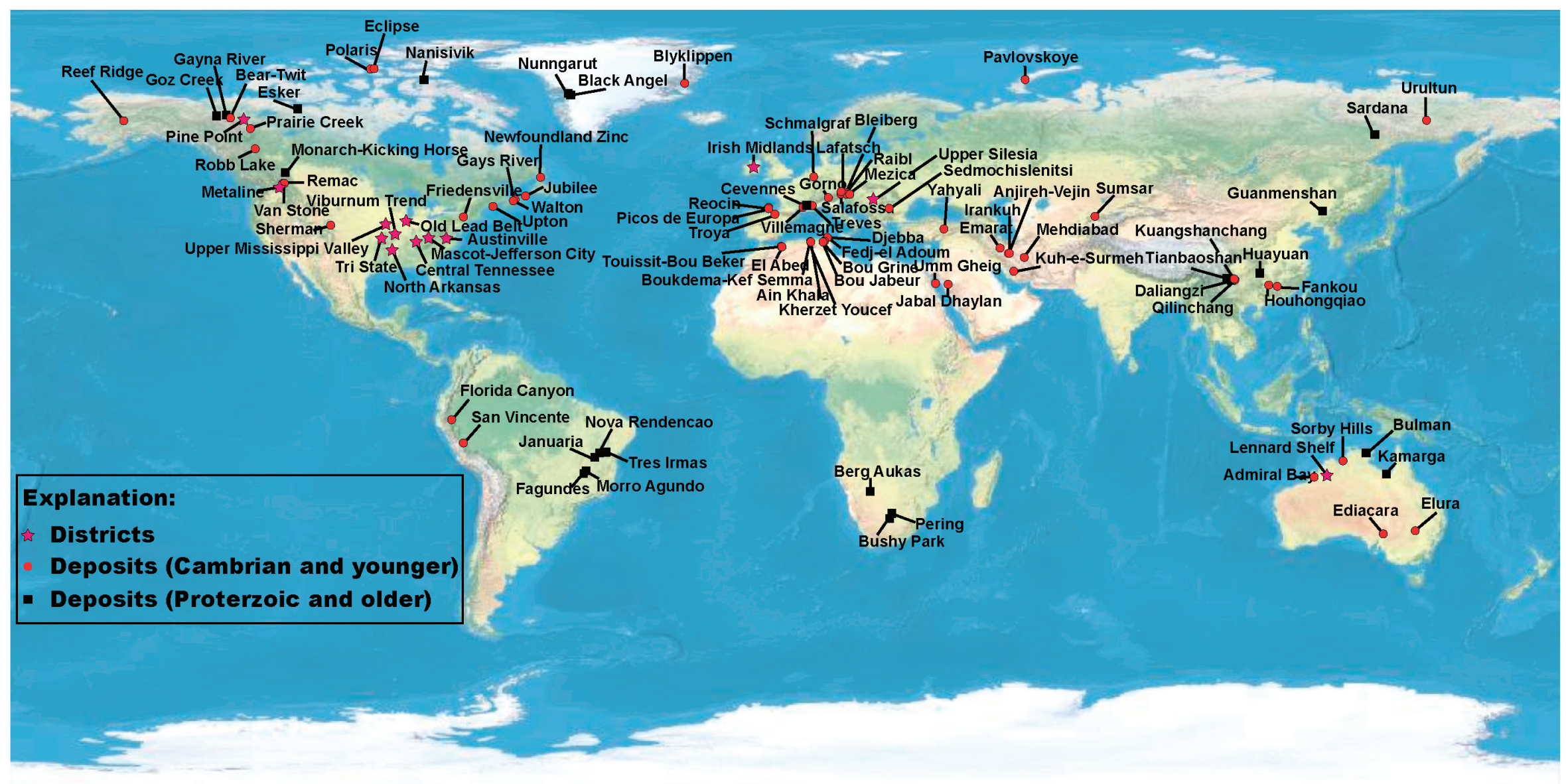

Figure B2. Global distribution of Mississippi Valley-type lead-zinc deposits and districts. 


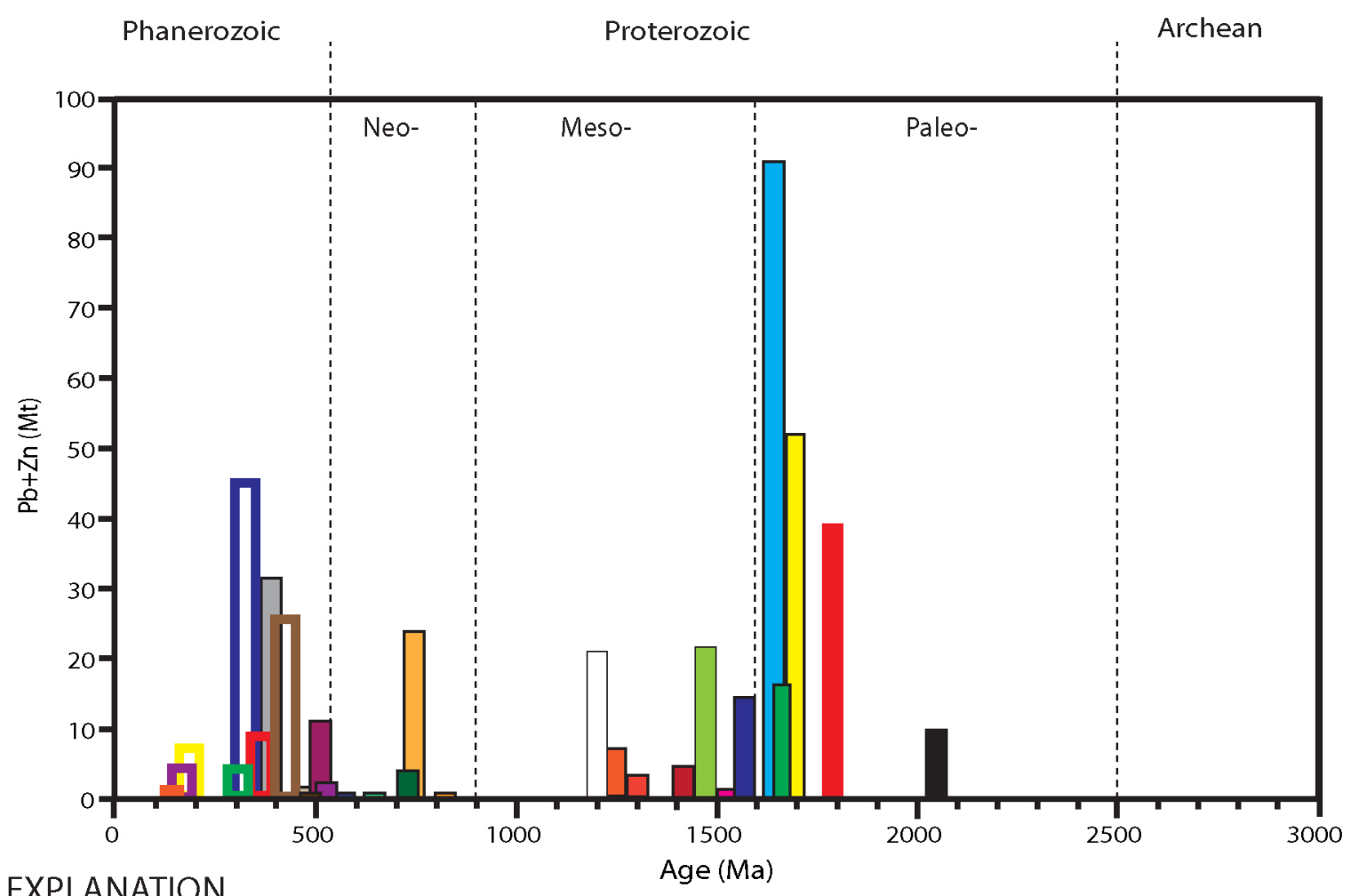

Dongshengmiao, North Park, Pinnacles

Ambaji, Bajta Central, Ballaria, Bamnia Kalan, Baroi, Bethumni, Deri, Devpura, Ganeshpura, Gorubathan, Kankariya, Kayar, Madarpura, Mochia, Mokanpura North, Paduna North Block, Rajpura-Dariba, Rampura-Agucha, Rangpo, Rewara, Saladipura, Samodi, Sawar, Sindesar Kalan East, Sindesar Khurd, South Dedwas, Tikhi, Tiranga, Zawarmala

$\square$ Broken Hill

$\square$ Cannington, Dugald River, Pegmont

$\square$ Hilton-George Fisher, HYC, Lady Loretta, Mount Isa

Century

Colby, Cottonbelt, River Jordan, Ruddock Creek

Sullivan

Big Syncline, Gaobanhe

$\square$ Balmat, Edwards

$\square$ Abu Samar, Cadieux, Canoas, Huogeqi, Hyatt, Jiashengpan, Kootenay King, Maramungee, Perau, Pierrepont, Tanyaokou

$\square$ Black Mountain, Broken Hill, Gamsberg

$\square$ Ganesh Himal

$\square$ Kholodninskoye

Big Ledge, Bleikvassli,Mofjellet, Rosh Pinah

$\square$ Tsongoari

Kushk

Angas, Duncan, H.B., Jersey, Maozu, Niujiaotang

Dy, Faro, Grum, Mount Torrens, Swim, Vangorda

Mel

Citronen Fjord

Bayindir

Howards Pass

Beishan, Bijiashan, Changba-Lijiagou, Clear Lake, Dengjiashan, Luoba, Meggen, Qiandongshan, Rammelsberg, Siding, Tongmugou, Triumph, Xidinggou, Yindongliang

Arrens, Bafangshan, Cirque, Driftpile, Jason, South Cirque, Tom

- Anarraaq, Lik, Qixiashan, Red Dog, Su

Dairi

Filizchai

- Castellanos, Duddar, Matahambre, Santa Lucia

Dongjiahe

Figure B3. Clastic-dominated lead-zinc deposits through time. Ages based on direct dating of ore mineralization or age of host-rock. Explanation list ordered from oldest to youngest deposits. 


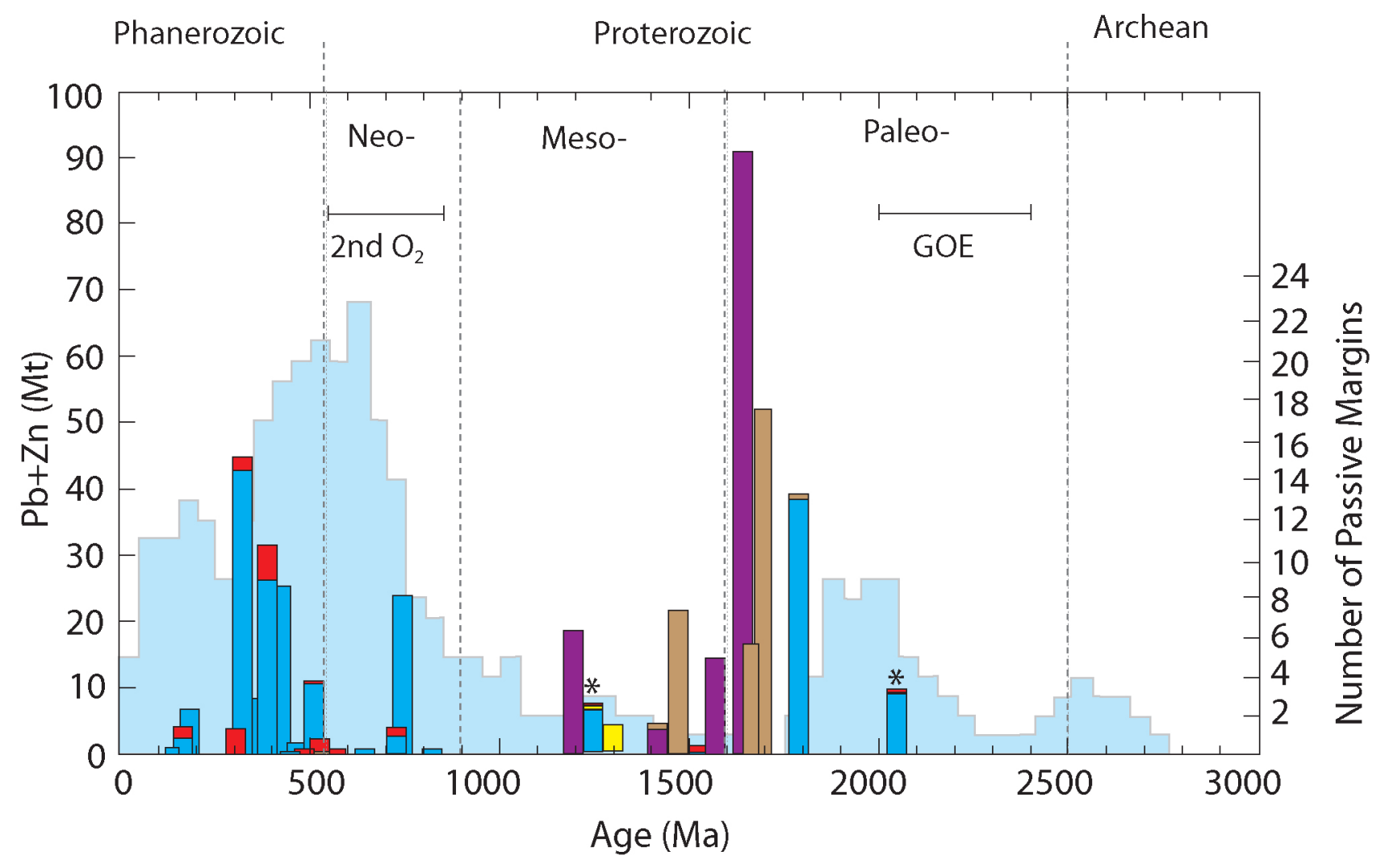

\section{EXPLANATION}

Tectonic Setting of Ore Deposition

$\square$ Unclassified

$\square$ Passive Margin

$\square$ Back-Arc Basin

$\square$ Continental Sag Basin

$\square$ Rift
Passive Margins

Through Time

* Indicates Poorly

Constrained Age

GOE Great Oxidization Event

2nd $\mathrm{O}_{2}$ Second Great Oxidization Event

Figure B4. Secular distribution of clastic-dominated lead-zinc deposits classified by their tectonic setting during mineralization. The number of passive margins through time are shown for comparison. Passive margins through time from Bradley, 2008. 


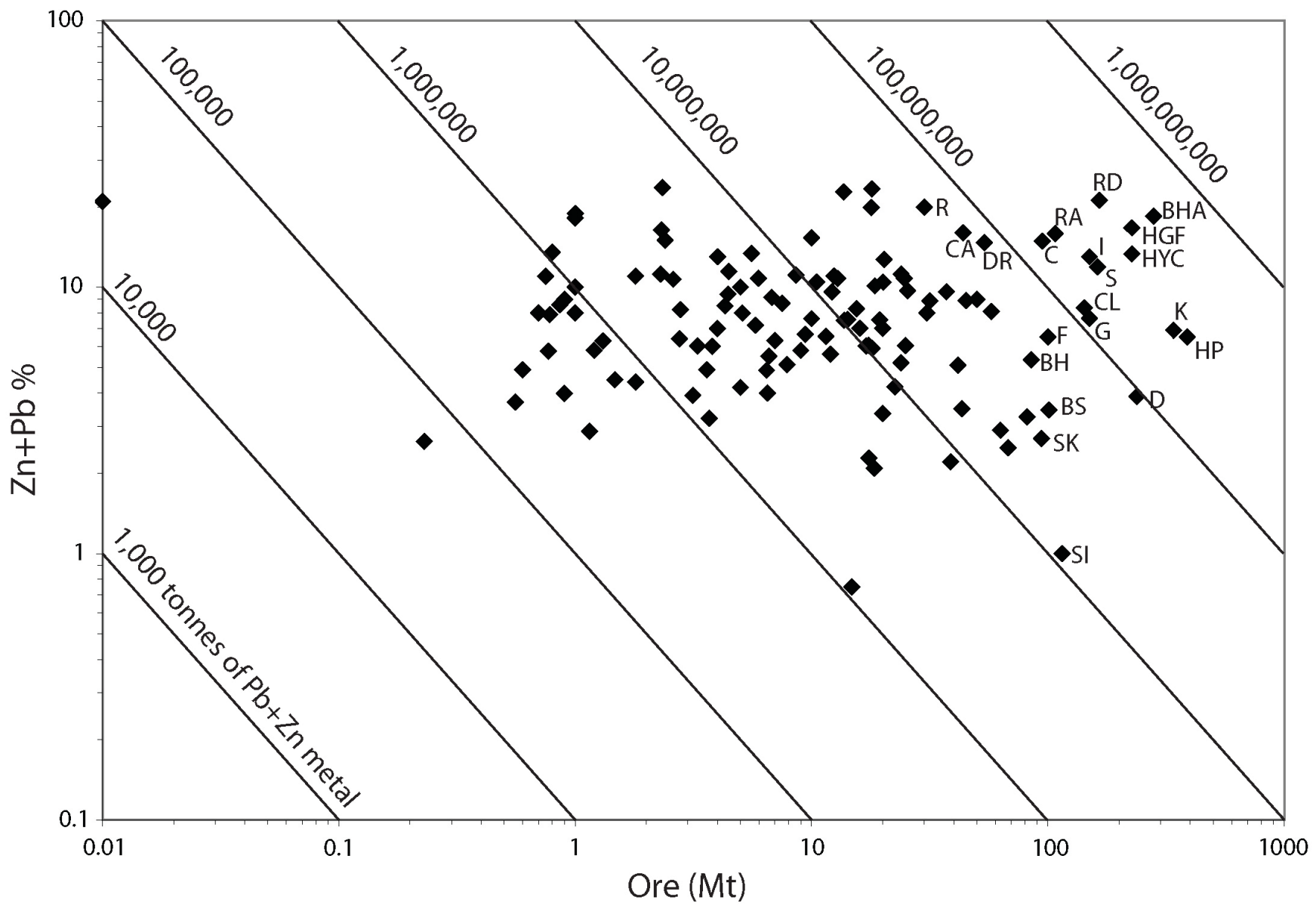

Figure B5. Grade/tonnage for 121 clastic-dominated lead-zinc deposits. Diagonal lines represent total tonnage of contained zinc and lead metal. Select deposits are labeled as: $\mathrm{BH}=$ Broken Hill, South Africa;

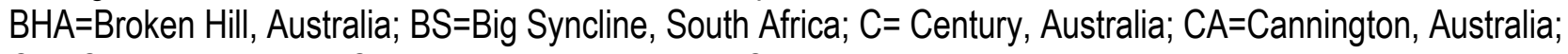
$\mathrm{CL}=$ Changba-Lijiagou, China; D=Dongshengmiao, China; $\mathrm{DR}=$ Dugald River, Australia; F=Filizchai, Azerbaijan; $\mathrm{G}=$ Gamsberg, Germany; HGF=Hilton-George Fisher, Australia; HP=Howards Pass, Canada; HYC=HYC, Australia; I=Mount Isa, Australia; K=Kholodninskoye, Russia; R=Rammelsberg, Germany; RA=RampuraAgucha, India; RD=Red Dog, USA; S=Sullivan, Canada; SI= Saldipura, India; SK= Sindesar Kalan East, India. 


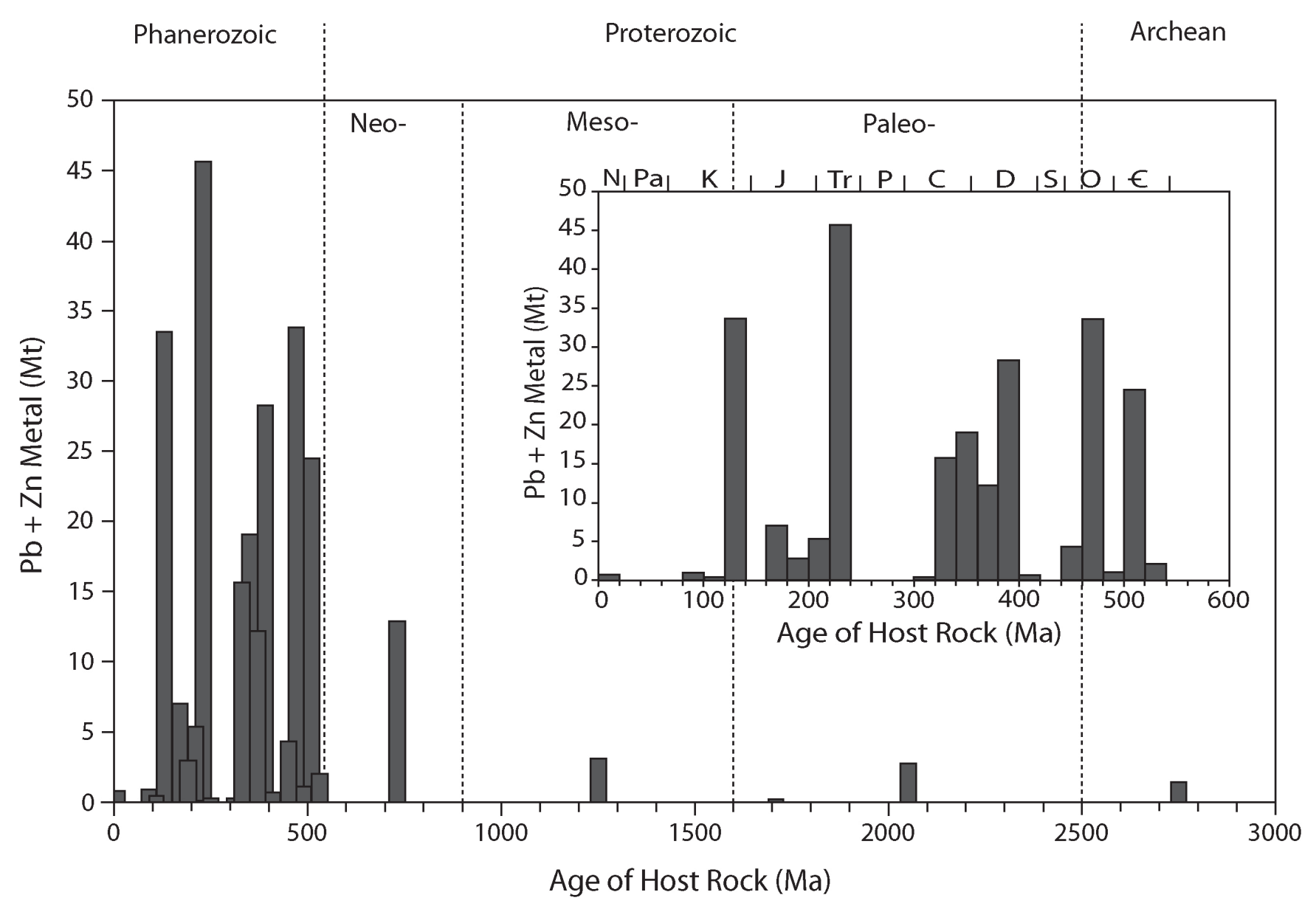

Figure B6. Secular distribution of Mississippi Valley-type metal and age of host rock. Data for 107 deposits and 10 districts are summarized from the Neoproterozoic to present. Mesoproterozoic deposits include Bulman and Nanisivik. Paleoproterozoic deposits include Black Angel, Esker, and Nunngarut. Archean deposits include Bushy Park-Pering. Inset shows a more detailed distribution of metal content from 600 Ma to present. 


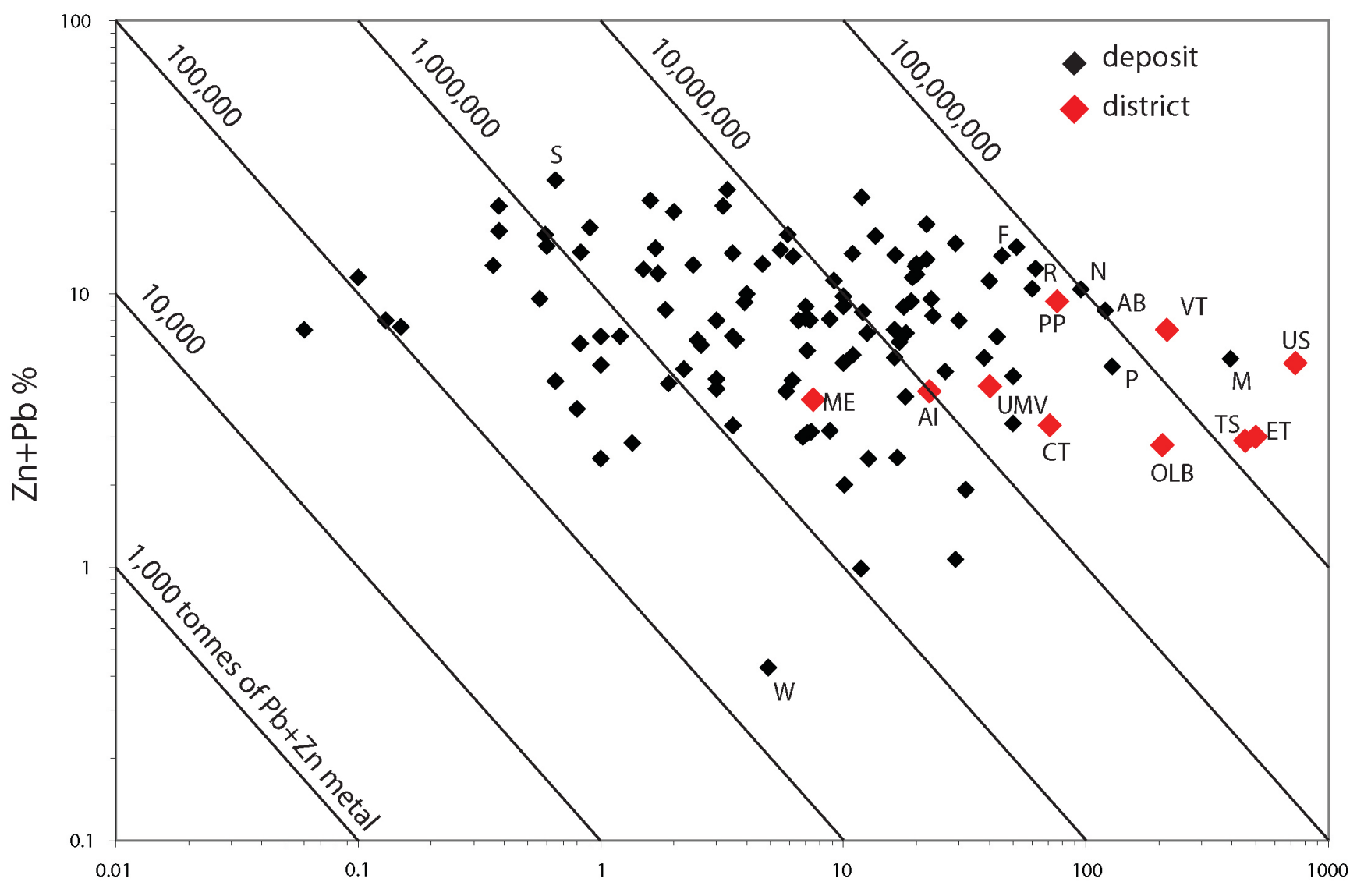

Ore $(\mathrm{Mt})$

Figure B7. Grade-tonnage for 113 Mississippi Valley-type deposits and 10 districts. Diagonal lines represent tonnage of $\mathrm{Pb}$ and $\mathrm{Zn}$ metal. Select districts and deposits are labeled as: $\mathrm{AB}=\mathrm{Admiral} B$ Bay, Australia; Al=Austinville-Ivanhoe, USA; CT=Central Tennessee, USA; ET=East Tennessee, USA; F=Fankou, China; M=Mehdiabad, Iran; ME=Metaline, USA; N=Navan, Ireland; OLB=Old Lead Belt, USA; P=Pavlovskoye, Russia; PP=Pine Point, Canada; R=Reocin, Spain; S=Schmalgraf, Belgium; TS=Tri-State, USA; UMV=Upper Mississippi Valley, USA; US=Upper Silesia, Poland; VT=Viburnum Trend, USA; W=Walton, Canada. 


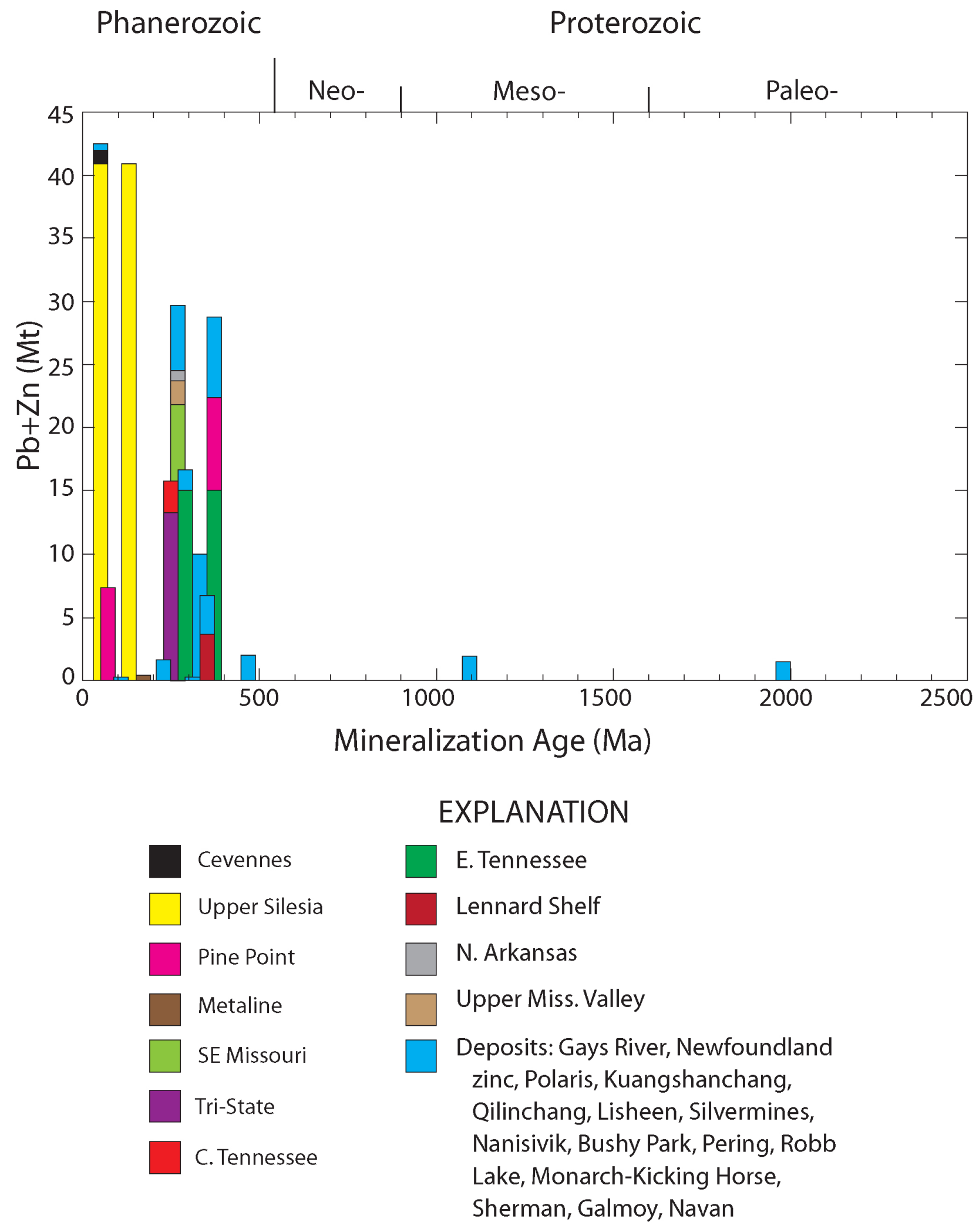

Figure B8. Age of mineralization for Mississippi Valley-type districts and deposits. Ages determined by paleomagnetism and/or radiometric dating. 


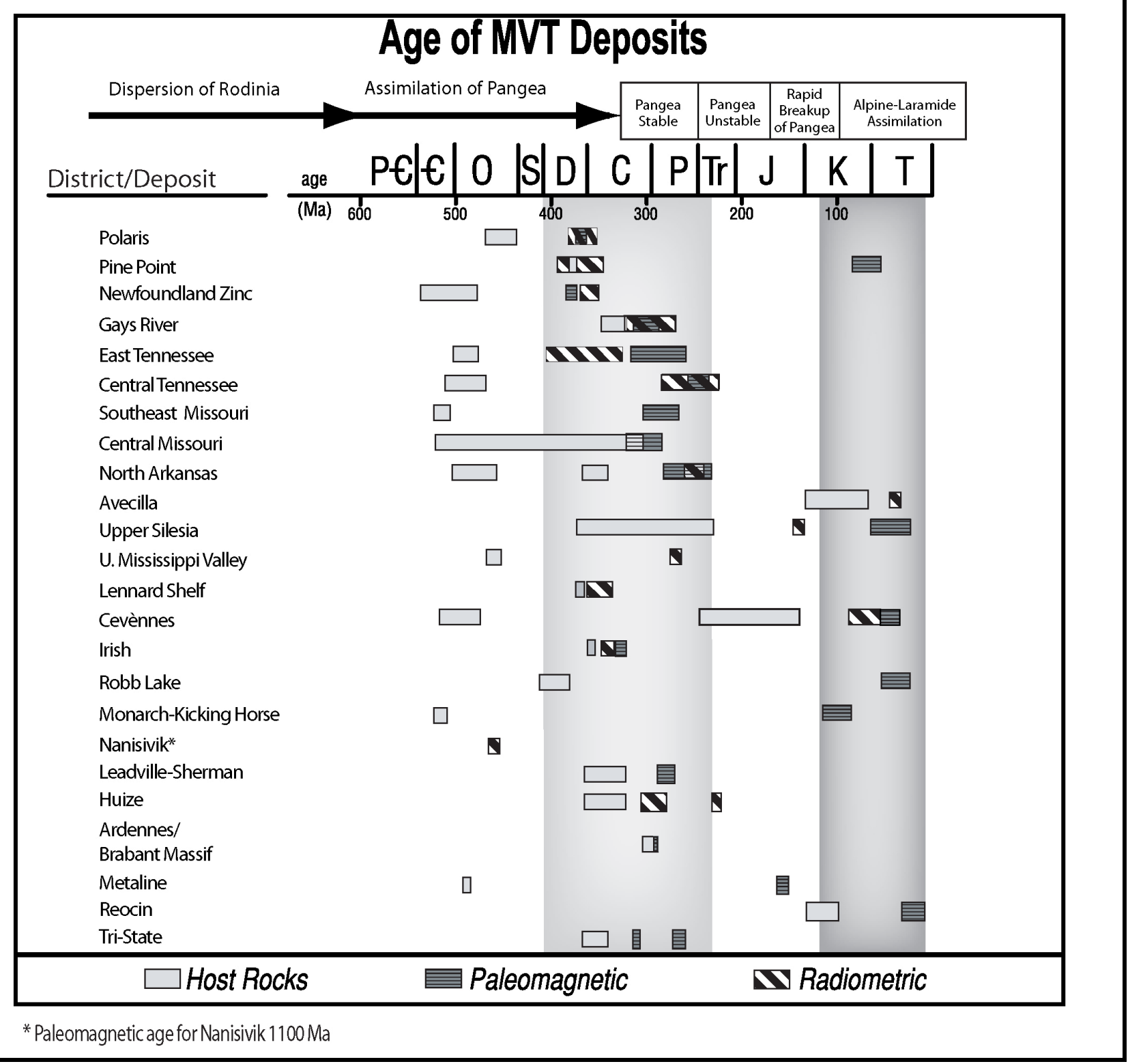

Figure B9. Ages of mineralization and host-rock for Mississippi Valley-type deposits and districts. The two shaded columns represent periods of tectonic assimilation and deposition of 97 percent of the total lead and zinc mineralization in dated Mississippi Valley-type deposits and districts. 